\title{
The Multifaceted Roles of Copper in Cancer: A Trace Metal Element with Dysregulated Metabolism, but Also a Target or a Bullet for Therapy
}

\author{
Pierre Lelièvre ${ }^{1}$, Lucie Sancey ${ }^{1}\left(\mathbb{D}\right.$, Jean-Luc Coll ${ }^{1} \mathbb{1}$, Aurélien Deniaud ${ }^{2, *} \mathbb{C}$ \\ and Benoit Busser 1,3,*(D) \\ 1 Institute for Advanced Biosciences, UGA INSERM U1209 CNRS UMR5309, 38700 La Tronche, France; \\ pierre.lelievre@univ-grenoble-alpes.fr (P.L.); lucie.sancey@univ-grenoble-alpes.fr (L.S.); \\ jean-luc.coll@univ-grenoble-alpes.fr (J.-L.C.) \\ 2 Univ. Grenoble Alpes, CNRS, CEA, IRIG, Laboratoire de Chimie et Biologie des Métaux, \\ 38000 Grenoble, France \\ 3 Department of Clinical Biochemistry, Grenoble Alpes University Hospital, 38043 Grenoble, France \\ * Correspondence: aurelien.deniaud@cea.fr (A.D.); bbusser@chu-grenoble.fr (B.B.); \\ Tel.: +33-438-78-9651 (A.D.); +33-632-393-765 (B.B.)
}

Received: 15 October 2020; Accepted: 27 November 2020; Published: 1 December 2020

Simple Summary: Copper is an essential element for human life. However, its redox activity can be detrimental for the cell that developed highly coordinated pathways to chelate and traffic copper through the cell or the organism. Owing to its important role in functions essential for cell growth and metabolism, copper concentrations are frequently dysregulated in tumors. In this review, we describe normal and cancer-altered copper homeostasis mechanisms. Moreover, on the basis of this knowledge, we expose not only copper-related diagnostic and prognostic markers for oncology but also therapeutic strategies to act on copper homeostasis to fight against cancer.

\begin{abstract}
In the human body, copper $(\mathrm{Cu})$ is a major and essential player in a large number of cellular mechanisms and signaling pathways. The involvement of $\mathrm{Cu}$ in oxidation-reduction reactions requires close regulation of copper metabolism in order to avoid toxic effects. In many types of cancer, variations in copper protein levels have been demonstrated. These variations result in increased concentrations of intratumoral $\mathrm{Cu}$ and alterations in the systemic distribution of copper. Such alterations in $\mathrm{Cu}$ homeostasis may promote tumor growth or invasiveness or may even confer resistance to treatments. Once characterized, the dysregulated $\mathrm{Cu}$ metabolism is pinpointing several promising biomarkers for clinical use with prognostic or predictive capabilities. The altered $\mathrm{Cu}$ metabolism in cancer cells and the different responses of tumor cells to $\mathrm{Cu}$ are strongly supporting the development of treatments to disrupt, deplete, or increase $\mathrm{Cu}$ levels in tumors. The metallic nature of $\mathrm{Cu}$ as a chemical element is key for the development of anticancer agents via the synthesis of nanoparticles or copper-based complexes with antineoplastic properties for therapy. Finally, some of these new therapeutic strategies such as chelators or ionophores have shown promising results in a preclinical setting, and others are already in the clinic.
\end{abstract}

Keywords: copper homeostasis; cancer; prognostic; diagnostic; therapy

\section{Introduction}

Trace elements such as copper $(\mathrm{Cu})$ are involved in many physiological processes. It has been shown that disturbances in copper homeostasis lead to structural abnormalities or loss of certain essential physiological functions. It has been clearly demonstrated that copper homeostasis 
is deregulated in many cancers. In addition, numerous studies showed that the deregulation of trace element homeostasis might be, at the same time, the cause and consequence of carcinogenesis. Some studies have also revealed that these dysregulations could be of clinical interest as a prognostic and/or predictive biomarker of a response to treatment. Accordingly, several therapeutic strategies targeting or using trace elements have been developed. In view of such rich literature, we present the most significant studies on cell mechanisms relating to $\mathrm{Cu}$ homeostasis dysregulation and cancer. This review is also an opportunity to present the discrepant results on this subject. Finally, in this work, we review the main therapeutic strategies targeting $\mathrm{Cu}$ or using $\mathrm{Cu}$ as a central player for cancer treatment.

\section{Copper Normal Metabolism}

$\mathrm{Cu}$ is an essential trace element with a short half-life of about a month. The required daily intake of $\mathrm{Cu}$ is $0.8 \mathrm{mg}$ [1]. $\mathrm{Cu}$ concentrations fluctuate from 1 to $10 \mathrm{mg} / \mathrm{g}$ of tissues, and the $\mathrm{Cu}$ concentration in blood plasma is approximately $1000 \mathrm{ng} / \mathrm{mL}$. However, $\mathrm{Cu}$ concentration may vary depending on various factors [2].

In the body, copper is present in two redox states, namely, $\mathrm{Cu}(\mathrm{I})$ and $\mathrm{Cu}(\mathrm{II})$. In fluids, $\mathrm{Cu}$ is in its $\mathrm{Cu}(\mathrm{II})$ state, and in the intracellular reducing environment, it is mainly found in its $\mathrm{Cu}(\mathrm{I})$ state. However, in redox enzymes, $\mathrm{Cu}$ is shuttling between $\mathrm{Cu}(\mathrm{I})$ and $\mathrm{Cu}(\mathrm{II})$. Cu plays an important role in various cellular functions. A list of $54 \mathrm{Cu}$-binding proteins was established using a bioinformatic approach (Table 1) [3]. However, this list is not exhaustive because of the fact that other copper-dependent proteins and/or proteins involved in copper metabolism may be discovered in the future. Cu is also involved in angiogenesis cellular mechanisms and in other signaling pathways [4-6].

Table 1. The different $\mathrm{Cu}$-binding proteins known in human cells. Inspired from Blockhuys, S et al. [3].

\begin{tabular}{|c|c|c|c|c|c|}
\hline $\begin{array}{c}\text { Cell } \\
\text { Membrane }\end{array}$ & $\begin{array}{l}\text { Intracellular } \\
\text { Vesicles }\end{array}$ & $\begin{array}{l}\text { Endoplasmic } \\
\text { Reticulum }\end{array}$ & Cytoplasm & \multicolumn{2}{|c|}{ Extracellular Space } \\
\hline ATP7A & TYR & MOXD1 & Atox1 & AOC1 & SOD3 \\
\hline SLC31A1 & TYRP1 & MOXD2P & CCS & $\mathrm{Cp}$ & AFP \\
\hline SLC31A2 & \multirow[b]{2}{*}{ Nucleus } & \multirow[b]{2}{*}{ Mitochondrion } & COMMD1 & $\mathrm{DBH}$ & ALB \\
\hline AOC2 & & & CUTC & ENOX1 & F5 \\
\hline AOC3 & COMMD1 & COX11 & LOXL3 & ENOX2 & GPC1 \\
\hline ENOX1 & CUTC & COX17 & MAP2K1 & LOX & LTF \\
\hline ENOX2 & LOXL2 & Sco1 & MEMO1 & LOXL1 & MT3 \\
\hline HEPH & MAP2K1 & $\mathrm{Sco} 2$ & SOD1 & LOXL2 & MT4 \\
\hline HEPHL1 & MEMO1 & MT-CO1 & MT3 & LOXL3 & S100A12/A13 \\
\hline PAM & PARK7 & MT-CO2 & PRNP & LOXL4 & SNCA \\
\hline PARK7 & SOD1 & PARK7 & S100A12/A13 & PAM & SPARC \\
\hline APP & LTF & PRNP & SNCA & \multirow{2}{*}{\multicolumn{2}{|c|}{ Golgi apparatus }} \\
\hline GPC1 & PRNP & CUTA & \multirow[b]{2}{*}{ Cytoskeleton } & & \\
\hline PRNP & S100A5 & & & \multicolumn{2}{|c|}{ ATP7A } \\
\hline S100A12 & S100B & & MAP2K1 & \multicolumn{2}{|c|}{ АТР7B } \\
\hline SNCA & SNCA & & S100A12 & \multicolumn{2}{|c|}{ PRNP } \\
\hline
\end{tabular}

Although essential for normal cell function, free $\mathrm{Cu}$ can induce toxicity to cells. In physiological conditions, $\mathrm{Cu}$ is always bound to peptides or proteins to prevent uncontrolled redox activity. Several cellular mechanisms allow the precise regulation of the spatial and temporal distributions of $\mathrm{Cu}$ (Figure 1A,B). In human cells, $\mathrm{Cu}$ is internalized by copper transport protein 1 (Ctr1) [7]. Additionally, 
a second $\mathrm{Cu}$ transport protein Ctr2 may be involved in copper transport, but it has a lower affinity for $\mathrm{Cu}$, and its role remains unclear [8]. The Ctr1 protein is trafficking between the plasma membrane and intracellular vesicles to control the entry of $\mathrm{Cu}$ into the cell. Thus, in the case of increased copper levels, Ctr1 is internalized in intracellular vesicles. The Ctr1 protein is essential for the stability of Ctr2, and Ctr1 and Ctr2 have interconnected functions in $\mathrm{Cu}$ homeostasis [9]. Finally, a model suggests that the regulation of systemic copper and intracellular mobilization involves the cleavage of the ecto-domain of Ctr1 that binds copper. Ctr2 may regulate the formation of the truncated form of Ctr1 (tCtr1) [10]. Moreover, the absence of Ctr2 leads to the accumulation of $\mathrm{Cu}$ in the endosomal compartments. Once in the cytoplasm, $\mathrm{Cu}$ is distributed through four main pathways (Figure 1A,B).

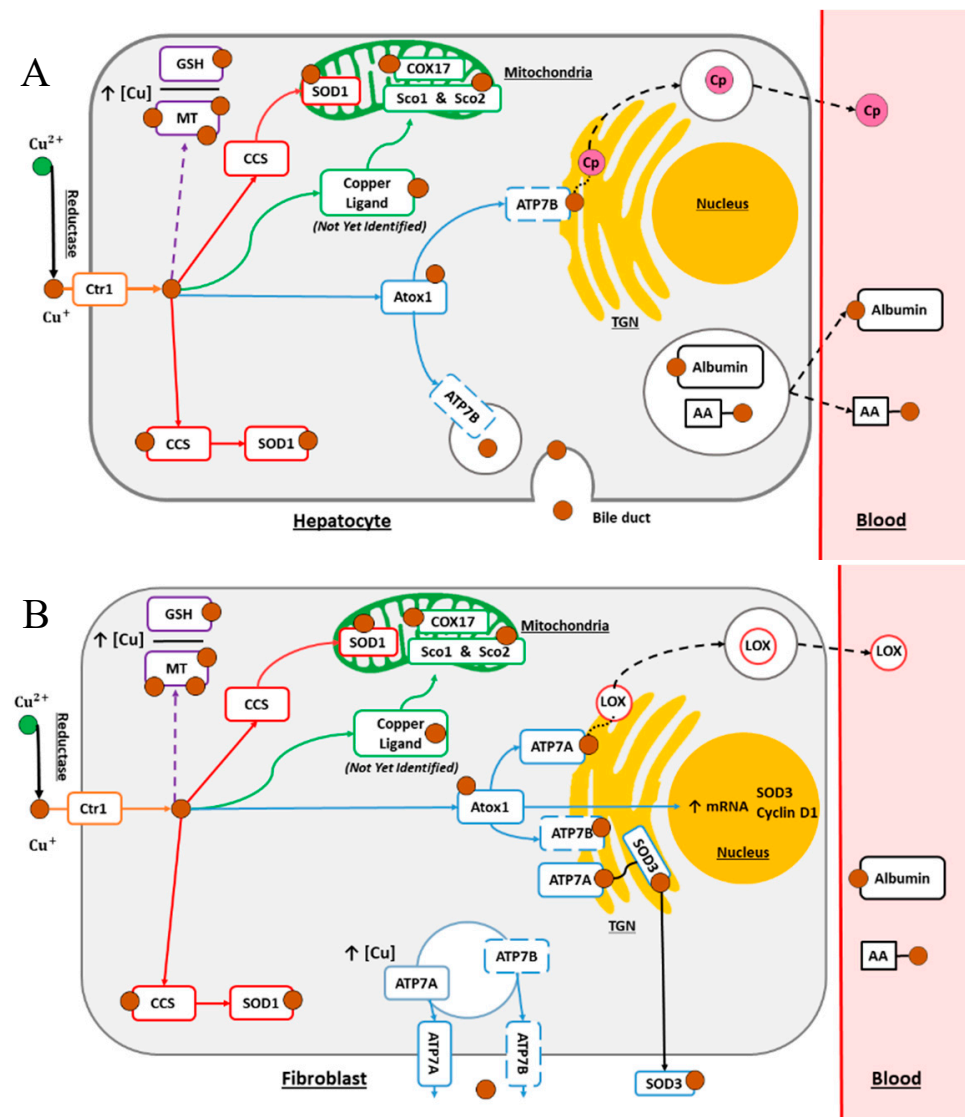

Figure 1. Cellular copper homeostasis in hepatocytes (A) and fibroblasts (B). In cells, the internalization of reduced $\mathrm{Cu}$ occurs via $\mathrm{Ctr1}$. Then, $\mathrm{Cu}$ is involved in the control of oxidative stress (red arrows) through a copper chaperone for superoxide dismutase protein (CCS) and cytoplasmic $\mathrm{Cu} / \mathrm{Zn}$ superoxide dismutase 1 (SOD1). Copper can be stored in its main storage reservoir, the mitochondria, where the proteins COX17, Sco1, and Sco2 play a role in its incorporation into complex IV of the respiratory chain (green arrows). Nevertheless, in the mitochondrial pathway, the identity of the chaperone that carries $\mathrm{Cu}$ across the mitochondrial membranes is not clearly identified. The excess $\mathrm{Cu}$ can also be sequestered by metallothioneins (MT) and/or bound by glutathione (GSH; dashed purple arrows). (A) In hepatocytes, copper can be secreted via the bile duct or released in the blood stream bound to ceruloplasmin $(\mathrm{Cp})$ after transport by Atox1 and ATP7B proteins (blue arrows) and transit in the trans-Golgi network (TGN). $\mathrm{Cu}$ is released into the blood stream and travels by binding to $\mathrm{Cp}$, amino acids (AA), or albumin. (B) In fibroblasts, ATP7A carries Cu from Atox1 to the TGN for its integration into lysyl oxidase (LOX) or extracellular superoxide dismutase 3 (SOD3) before their extracellular release. In addition, the excess intracellular $\mathrm{Cu}$ can be removed from the cell through ATP7A and ATP7B. 


\subsection{The Secretory Pathway}

The cytoplasmic $\mathrm{Cu}$ chaperone, antioxidant-1 protein (Atox1), brings $\mathrm{Cu}$ to copper transport ATPases, namely, ATP7A and ATP7B. Both are present at the trans-Golgi network level, importing $\mathrm{Cu}$ into the Golgi apparatus lumen for the maturation of $\mathrm{Cu}$-dependent target enzymes such as ceruloplasmin (Cp), lysyl oxidase (LOX), tyrosinase, or extracellular $\mathrm{Cu} / \mathrm{Zn}$ superoxide dismutase 3 (SOD3), which are all secreted by exocytosis. Concerning SOD3, it has been shown that the $\mathrm{Cu}$ acquisition pathway for SOD3 involves at the same times the Atox 1 chaperone and copper transporter ATP7A in the trans-Golgi network [6]. Moreover, it turns out that Atox1 has a dual function, and it is a copper-dependent transcription factor for SOD3 and cyclin D1 [11]. In this Cu transport pathway, it was also shown that vascular ATP7A is necessary for the complete activation of SOD3 via a Cu-dependent interaction [6]. $\mathrm{Cu}$ bound to $\mathrm{Cp}$ is the main form of $\mathrm{Cu}$ in the blood (80-90\%). Cp is mainly synthetized in hepatocytes and in the kidneys, placenta, breast, or brain. Macrophages and mononuclear cells from the blood can also produce Cp during inflammation [2]. The LOX enzyme is synthesized into an inactive proenzyme that goes through a proteolytic treatment to obtain a mature enzyme and propeptide $[12,13]$. This enzyme ensures the reticulation of collagen and elastin to preserve the rigidity and structural stability of the extracellular matrix. Tyrosinase is a copper-containing monooxygenase, a major enzyme involved in the critical stage of the melanin pigment biosynthesis pathway [14].

As soon as intracellular $\mathrm{Cu}$ concentration increases and is in excess, both ATP7A/B proteins are relocated to the plasma membrane to excrete $\mathrm{Cu}$ out of the cell [7]. The expression levels of ATP7A and ATP7B vary depending on the tissue. The ATP7A protein (Menkes' protein) is expressed in all cell types, except hepatocytes. The ATP7B protein (Wilson's protein) is mainly expressed in the liver and in the kidney, placenta, heart, brain, and lung tissues [15]. ATP7B is central for $\mathrm{Cu}$ homeostasis in the liver and thereof at the organismal level because the liver regulates the $\mathrm{Cu}$ concentrations in the blood. Indeed, this protein ensures the excretion of copper from hepatocytes to the bile in response to $\mathrm{Cu}$ overload, which is the main process to decrease $\mathrm{Cu}$ level in an organism. In addition, in plasma or other fluids, $\mathrm{Cu}$ is bound to different amino acids, peptides, or proteins such as histidine, albumin, transcuprein, or metallothioneins [16-19]. The secretory pathway can be subject to disruptions due to mutations in the genes coding for the proteins ATP7A or ATP7B, leading to Wilson's and Menkes diseases, respectively. The former is an inherited autosomal recessive genetic disease resulting in copper accumulation in the body, principally in the liver and brain, and triggering hepatic and neuropsychiatric symptoms [20]. Menkes disease is an X-linked recessive disorder in which patients lack $\mathrm{Cu}$, which induces growth delays and nervous system alteration

\subsection{The Cytosolic Pathway}

The copper chaperone for superoxide dismutase (CCS) protein transports $\mathrm{Cu}$ toward intracellular dimeric $\mathrm{Cu} / \mathrm{Zn}$ superoxide dismutase 1 (SOD1) in the cytosol and mitochondrial intermembrane space (IMS) [6] (Figure 1A,B). The proteins of the SOD family are key players in the defense against oxidative stress because it catalyzes the degradation of superoxide anions into hydrogen peroxide and oxygen [6]. Several isoforms of SOD exist including SOD2, which is a mitochondrial manganese (Mn) containing enzyme (MnSOD) and two others, which contain $\mathrm{Cu}$. These two other enzymes are the intracellular dimeric $\mathrm{Cu} / \mathrm{Zn}-\mathrm{SOD}$ (SOD1) and extracellular tetrameric $\mathrm{Cu} / \mathrm{Zn}$ superoxide dismutase 3 (SOD3) as seen previously.

In the cytosol, $\mathrm{Cu}$ can be directly bound to a multitude of kinases. We can cite the interaction between copper and the kinases of the serine/threonine-protein kinase B-raf (BRAF) signaling pathway being dual specificity mitogen-activated protein kinase kinase mek-1/2 (MEK1/2) [21]. Recently, another metal-kinase interaction has been demonstrated. Moreover, $\mathrm{Cu}$ is necessary for the activity of the autophagic serine/threonine-protein kinase ULK1 and serine/threonine-protein kinase ULK2 (ULK1/2) via a direct $\mathrm{Cu}-\mathrm{ULK} 1 / 2$ linkage [22]. 
To conclude, copper $(\mathrm{Cu})$ is able to bind to various cytosolic proteins such as growth factors, cell signaling proteins, or structural proteins [23]. Within the cell, $\mathrm{Cu}$ can directly regulate the activity of these protein partners such as kinases. Therefore, many signaling pathways are copper dependent.

\subsection{The Mitochondrial Pathway}

Copper is an important trace element in the physiology of the mitochondria, which also have an essential role in copper homeostasis [24]. Cu is actively transported to the mitochondrial matrix, where it is required to mature in a first instance cytochrome c oxidase (COX), which is complex IV of the respiratory chain. The assembly of COX requires different subunits and cofactors added in a sequential and orderly process [25]. The identity of the chaperone driving $\mathrm{Cu}$ through the mitochondrial membranes is not clearly established, but it could be either COX17 or a non-protein metallophore of unknown identity, and it is named Cu ligand (Figure 1A,B) [26]. Moreover, recent research conducted by Cobine et al. has shown that the mammalian phosphate carrier SLC25A3 is a mitochondrial copper transporter necessary for the biogenesis of cytochrome c oxidase [27]. Within the mitochondria, the metallochaperones synthesis of cytochrome c oxidase 1 (Sco1) and synthesis of cytochrome c oxidase 2 (Sco2; Figure 1A,B) are then involved in further $\mathrm{Cu}$ insertion into the COX. Being the main intracellular $\mathrm{Cu}$ storage reservoir, the mitochondria host a $\mathrm{Cu}$-dependent energy production via oxidative phosphorylation $[7,28]$.

\subsection{Cellular Processes for Metal Detoxification}

In cells, $\mathrm{Cu}$ is also stored in lysosomes [29,30]. Metallo-reductases, such as the human 6-transmembrane epithelial antigen of prostate (STEAP) family proteins, are necessary to maintain copper in its $\mathrm{Cu}(\mathrm{I})$ state because lysosomes are an oxidative environment. These reductases, principally STEAP3 and STEAP4, are located in intracellular vesicles and are involved in many biological processes, such as the regulation of cell proliferation and apoptosis [31,32].

Metallothioneins (MTs) and glutathione (GSH) are other important players for intracellular storage and sequestration of excess $\mathrm{Cu}$. Metallothioneins are cysteine-rich cytosplasmic proteins. They play an important role in the homeostasis and detoxification of metals. They have the ability to bind to metals such as $\mathrm{Cu}$ and zinc (Zn). In humans, there are four distinct MTs, identified as MT1, MT2, MT3, and MT4. MT1 and MT2 are the main ones, inducible via numerous stimuli. The MT3 and MT4 proteins are mainly expressed in the central nervous system [33]. The GSH is involved not only in several mechanisms such as xenobiotics metabolism and redox signaling but also in the transfer and detoxification of metal ions such as $\mathrm{Cu}[34,35]$. The majority of cytosolic copper is found in $\mathrm{Cu}(\mathrm{I})-\mathrm{GSH}$ complexes. Indeed, this complex is considered a major contributor to the exchangeable pool of $\mathrm{Cu}$ in the cytosol. However, this point is subject to debate in the scientific community [36,37].

\section{Copper Metabolism in Cancers}

When compared with nonpathological conditions, variations in $\mathrm{Cu}$ concentrations or in the $\mathrm{Cu} / \mathrm{Zn}$ ratios were associated with many cancers. The $\mathrm{Cu} / \mathrm{Zn}$ ratio is of clinical importance because of its relationship with aging, nutritional status, oxidative stress, inflammation, and immune abnormalities [38,39]. Increased $\mathrm{Cu}$ levels were associated with decreased $\mathrm{Zn}$ levels in a meta-analysis in bladder cancer [40] and in breast cancer, colorectal cancer (CRC), and prostate cancers [41-47]. Importantly, some discrepant studies reported decreases in $\mathrm{Cu}$ levels in CRC and breast cancers [48,49].

$\mathrm{Cu}$ is important for functions involved in proliferation or angiogenesis, which are central for tumorigenesis and cancer development. Copper is acting on different molecular pathways leading to a proangiogenic response necessary for carcinogenesis processes. It appears that copper also influences the spread and formation of secondary tumors via the activation of enzymes responsible for cell proliferation. It is therefore not surprising that $\mathrm{Cu}$ concentration is increased in tumor areas [50-52]. More recently, it was shown that specific $\mathrm{Cu}$ accumulation can be observed in cancer 
cells themselves $[51,53]$. It is worth noting that the accumulation of $\mathrm{Cu}$ in the nuclear region has been found in breast cancer cells [54].

Moreover, early reports described the increases of serum $\mathrm{Cu}$ in cancer patients, sometimes even correlated with the grade of the cancer [55]. High serum $\mathrm{Cu}$ levels were also found in cancer patients resistant to chemotherapy compared to patients responding to treatment [55]. However, this remains unexplained up to now, and several data on different types of cancer where published, sometimes being contradictory.

More recently, isotopic fractionation was developed for biological samples, usually measured in blood. It has been shown that the isotopic ${ }^{63} \mathrm{Cu} /{ }^{65} \mathrm{Cu}$ ratio is modified in the serum of cancer patients [56], where the lighter isotope is enriched in the blood. This phenomenon could be due to metabolism modifications in cancers such as increased glycolysis, and therefore higher lactate production. This would explain the higher excretion of ${ }^{63} \mathrm{Cu}$ by ATP7A in the blood stream. Moreover, it has been shown that the $\mathrm{Cu}$ isotopic ratio can be used as an early diagnostic biomarker for cancer, usable several months before other classical protein markers. Since $\mathrm{Cu}$ turnover is short (i.e., about one month), it is also convenient as a follow-up marker during treatment to monitor therapeutic efficacy.

Altogether, it is clear that $\mathrm{Cu}$ is central for cancer development at each step from tumorigenesis to metastasis. Cancer cell metabolism is also affecting Cu metabolism. Therefore, it is expected that prognostic and diagnostic markers for cancer can be identified in relation with $\mathrm{Cu}$.

\section{The Use of Copper Proteins as Cancer Biomarkers}

As discussed earlier, it is now widely accepted that disruption of copper homeostasis occurs in several cases of cancer. This can be linked with increases or decreases in protein levels. Large-scale studies such as the analysis of TCGA data in breast cancer revealed an increase in several copper-related proteins, including ATP7B and Ctr1 [3]. Moreover, Ctr1, Sco1, and COX11 were increased in a transcriptomic analysis of copper homeostasis genes in CRC samples [57]. Consequently, copper homeostasis proteins appear to be promising candidates as predictive biomarkers of the treatment response or as prognostic biomarkers, and their clinical use may guide the choice for optimal therapeutic strategy in the future (Table 2).

Table 2. Cu proteins affected in cancers and their prognostic relevance.

\begin{tabular}{|c|c|c|c|c|c|}
\hline Altered Player & Regulation & Sample & Cancer & Prognostic & Ref. \\
\hline Atox1 & + & Tissue & Breast Invasive Cancer & poor & [3] \\
\hline Atox1 & + & Tissue & Melanoma & poor & [58] \\
\hline Atox1 & + & Tissue & Skin Cancer & & [58] \\
\hline Atox1 & + & & Blood & & [58] \\
\hline Atox1 & + & Tissue & Colorectal Cancer & poor & [59] \\
\hline ATP7A & + & Tissue & Pancreatic Cancer & & {$[60]$} \\
\hline ATP7A & + & Tissue & Breast Invasive Cancer & poor & [61] \\
\hline ATP7A & + & Tissue/cell lines & Lung Cancer & poor & [62] \\
\hline ATP7A & + & Tissue & Colorectal Cancer & & {$[57,63]$} \\
\hline ATP7A & + & Tissue/cell lines & Ovarian Cancer & poor & {$[64,65]$} \\
\hline ATP7B & + & Tissue & Esophageal Carcinoma & poor & [66] \\
\hline ATP7B & + & Tissue & Endometrial Carcinoma & poor & {$[67]$} \\
\hline ATP7B & + & Tissue & Breast Invasive Cancer & poor & [68] \\
\hline ATP7B & + & Tissue & $\begin{array}{c}\text { Oral Squamous Cell } \\
\text { Carcinoma }\end{array}$ & poor & [69] \\
\hline
\end{tabular}


Table 2. Cont.

\begin{tabular}{|c|c|c|c|c|c|}
\hline Altered Player & Regulation & Sample & Cancer & Prognostic & Ref. \\
\hline ATP7B & + & Tissue & Gastric Carcinoma & poor & [70] \\
\hline АТР7B & + & Tissue & Hepatocellular Carcinoma & poor & [71] \\
\hline LOX-1 & + & Tissue & Pancreatic Cancer & poor & [72] \\
\hline LOX-1 & + & Tissue & Prostate Cancer & poor & [73] \\
\hline LOX & + & Tissue & Colorectal Cancer & poor & [74] \\
\hline LOX-2 & + & Tissue/Serum & Hepatocellular Carcinoma & poor & [75] \\
\hline LOX & + & Tissue & Breast Invasive Cancer & poor & [76-78] \\
\hline LOX & - & Tissue & Bronchogenic Carcinoma & poor & [79] \\
\hline LOX & - & Tissue/cell lines & Gastric Cancers & & [80] \\
\hline LOX & + & Tissue & $\begin{array}{c}\text { Head and Neck Squamous } \\
\text { Cell Carcinoma }\end{array}$ & poor & [81] \\
\hline LOX & + & Tissue/cell lines & Lung Adenocarcinoma & poor & {$[82,83]$} \\
\hline LOX & + & Cell lines & Melanoma & poor & {$[76]$} \\
\hline LOX & + & Tissue & $\begin{array}{c}\text { Oral and Oropharyngeal } \\
\text { Squamous Cell }\end{array}$ & poor & [84] \\
\hline LOX & - & Tissue/cell lines & $\begin{array}{c}\text { Basal and Squamous Cell } \\
\text { Carcinomas }\end{array}$ & & [85] \\
\hline LOX & + & Tissue & Renal Cell Carcinoma & & [86] \\
\hline LOXL1 & - & Cell lines & Bladder Cancer & & [87] \\
\hline LOXL4 & - & Cell lines & Bladder Cancer & & [87] \\
\hline LOXL1 & + & Cell lines & Lung Adenocarcinoma & & [88] \\
\hline LOXL1 & + & Tissue & $\begin{array}{c}\text { Salivary Gland Adenoid } \\
\text { Cystic Carcinoma }\end{array}$ & & [89] \\
\hline LOXL2 & + & Tissue/cell lines & Breast Invasive Cancer & poor & [90-94] \\
\hline LOXL2 & + & Tissue & Colorectal Cancer & poor & {$[93,95-97]$} \\
\hline LOXL2 & + & Tissue/cell lines & Gastric Cancers & poor & {$[93,98]$} \\
\hline LOXL2 & + & Tissue & Endometrial Cancer & poor & [94] \\
\hline LOXL2 & + & Tissue & Testicular Cancer & poor & [94] \\
\hline LOXL2 & + & Tissue & Hepatocellular Carcinoma & poor & [94] \\
\hline LOXL2 & + & Tissue & $\begin{array}{l}\text { Lung Squamous Cell } \\
\text { Carcinoma }\end{array}$ & poor & {$[90,99]$} \\
\hline LOXL2 & + & Cell lines & Melanoma & poor & [76] \\
\hline LOXL2 & + & Tissue/cell lines & Pancreatic Cancer & poor & {$[94,100]$} \\
\hline LOXL2 & + & Tissue & Prostate Cancer & poor & {$[101]$} \\
\hline LOXL2 & + & Tissue & Renal Cell Carcinoma & poor & [94] \\
\hline LOXL2 & + & Tissue & Laryngeal Cancer & poor & {$[90,94]$} \\
\hline LOXL2 & + & Tissue & Esophageal Squamous Cell & poor & {$[94,102]$} \\
\hline LOXL3 & + & Cell lines & Breast Invasive Cancer & & [103] \\
\hline LOXL3 & + & Cell lines & Melanoma & & {$[76,103]$} \\
\hline LOXL4 & + & Tissue & $\begin{array}{c}\text { Colorectal } \\
\text { Adenocarcinoma }\end{array}$ & & [95] \\
\hline
\end{tabular}


Table 2. Cont.

\begin{tabular}{|c|c|c|c|c|c|}
\hline Altered Player & Regulation & Sample & Cancer & Prognostic & Ref. \\
\hline LOXL4 & + & Tissue/cell lines & $\begin{array}{c}\text { Head and Neck Squamous } \\
\text { Cell Carcinoma }\end{array}$ & & [104-106] \\
\hline Ctr1 & + & Tissue & Colorectal Cancer & & {$[57]$} \\
\hline Sco1 & + & Tissue & Colorectal Cancer & & [57] \\
\hline COX11 & + & Tissue & Colorectal Cancer & & [57] \\
\hline Ctr1 & + & Tissue & $\begin{array}{l}\text { Non-Small-Cell Lung } \\
\text { Cancer }\end{array}$ & good & [107] \\
\hline Ctr1 & Variable & Tissue & Ovarian Cancer & & [108] \\
\hline Ctr2 & Variable & Tissue & Ovarian Cancer & & [108] \\
\hline Ctr1 & + & Cell lines & Ovarian Cancer & & [109] \\
\hline Ctr1 & + & Tissue & Breast Invasive Cancer & & [3] \\
\hline $\mathrm{Cu}$ & + & Serum & Bladder Cancer & & [40] \\
\hline $\mathrm{Zn}$ & - & Serum & Bladder Cancer & & [40] \\
\hline $\mathrm{Cu}$ & + & Serum & Breast Invasive Cancer & & $\begin{array}{c}{[42,44,49,} \\
110]\end{array}$ \\
\hline $\mathrm{Cu} / \mathrm{Zn}$ & + & Serum & Breast Invasive Cancer & & {$[42,44,110]$} \\
\hline $\mathrm{Cu}$ & + & Serum/Tissue & Lung Cancer & & {$[51,53]$} \\
\hline $\mathrm{Cu} / \mathrm{Zn}$ & + & Serum & Lung Cancer & & [51] \\
\hline $\mathrm{Cu}$ & \pm & Serum/Tissue & Colorectal Cancer & & {$[41,45,48]$} \\
\hline $\mathrm{Cu} / \mathrm{Zn}$ & + & Serum/Tissue & Colorectal Cancer & & {$[41,45,48]$} \\
\hline $\mathrm{Cu} / \mathrm{Zn}$ & + & Serum & Pancreatic Cancer & & {$[46]$} \\
\hline $\mathrm{Cu}$ & - & Serum & Pancreatic Cancer & & {$[46]$} \\
\hline $\mathrm{Cu}$ & + & Serum & $\begin{array}{l}\text { Cervical Cancer and } \\
\text { Uterine Myoma }\end{array}$ & & [47] \\
\hline $\mathrm{Cu} / \mathrm{Zn}$ & + & Serum & $\begin{array}{c}\text { Cervical Cancer and } \\
\text { Uterine Myoma }\end{array}$ & & [47] \\
\hline $\mathrm{Cu}$ & + & Serum & Prostate Cancer & & [43] \\
\hline $\mathrm{Cu}$ & + & Serum & $\begin{array}{c}\text { Papillary Thyroid } \\
\text { Carcinoma }\end{array}$ & & [111] \\
\hline $\mathrm{Cu}$ & - & Serum & Endometrial Cancer & & [112] \\
\hline GSH & + & Tissue & Hepatocellular Carcinoma & & [113] \\
\hline CCS & + & Tissue & Brain Cancer & & [58] \\
\hline CCS & + & Tissue & Ovarian Cancer & & {$[58]$} \\
\hline CCS & - & Tissue & Hepatocellular Carcinoma & & {$[58]$} \\
\hline CCS & - & Tissue & Prostate Cancer & & {$[58]$} \\
\hline SOD3 & - & Tissue & Lung Cancer & poor & [114-116] \\
\hline SOD3 & - & Tissue & Breast Invasive Cancer & poor & {$[117,118]$} \\
\hline SOD3 & - & Tissue & Prostate Cancer & poor & {$[119,120]$} \\
\hline SOD3 & - & Tissue & Pancreatic Cancer & poor & [121] \\
\hline SOD3 & - & Tissue & Colorectal Cancer & & [122] \\
\hline
\end{tabular}


Table 2. Cont.

\begin{tabular}{cccccc}
\hline Altered Player & Regulation & Sample & Cancer & Prognostic & Ref. \\
\hline SOD3 & - & Cell lines & Thyroid Cancer & {$[123]$} \\
\hline SOD3 & + & Serum & Gastric Adenocarcinoma & {$[124]$} \\
\hline COX17 & + & Cell lines & Lung Cancer & {$[125]$} \\
\hline COX17 & + & Tissue & $\begin{array}{c}\text { Head and Neck Squamous } \\
\text { Cell Carcinomas }\end{array}$ & {$[126]$} \\
\hline
\end{tabular}

\subsection{Involvement of Copper Metabolism Proteins in Metastasis Formation}

Studies have demonstrated that the deregulation of certain copper metabolism proteins has an impact on the migration of cells and on the formation of metastasis.

The Atox 1 protein is increased in many types of cancer tissues [3]. In blood, breast, and skin cancers, the mRNA levels of Atox1 are significantly higher compared to those in nonpathological tissues (Table 1) [58]. Moreover, it has been shown that Atox1 has a role in the migration of cancer cells in breast cancer [127]. This protein also promotes inflammatory neovascularization through its putative action as a transcription factor and as a cytoplasmic $\mathrm{Cu}$ chaperone [4]. Atox1 may be a potential prognostic biomarker for estrogen-receptor (ER)-positive and early stages of breast cancers because increased expression levels of Atox 1 correlated with poor survival for stages 1 and 2 breast cancers. However, preclinical studies and clinical trials are required to better understand the carcinogenic role of Atox1 [128]. In melanoma, a correlation between the overexpression of Atox1 and poor prognosis was observed because the knockdown of Atox1 decreased cell growth and BRAF V600E-dependent signaling in human melanoma cell lines [58]. From a tissue microarray, the increased nuclear translocation of Atox1 was observed in metastatic CRC and was correlated with the severity of the disease [59]. The nuclear localization of Atox1 was also correlated with increased migration capabilities in breast cancer cells in an ATP7A- and LOX-dependent mechanism [129]. Indeed, the colocalization of the three proteins, namely, Atox1, ATP7A, and LOX, was observed at the lamellipodia border of the cell. The reason is unclear, but it could be a way to maximize LOX maturation close to its excretion site, where it plays a major role in cancer cell migration and metastasis. Concerning the ATP7A protein, it is also deregulated in many cancers, such as in pancreatic cancer, where ATP7A is upregulated compared to that in chronic pancreatitis [60]. The ATP7A protein plays an important role in the formation of metastases in breast cancer and induces the migration of vascular smooth muscle cells [130]. In addition, high levels of ATP7A expression in primary tumors are associated with reduced survival according to publicly available databases [131].

Finally, the family of copper-dependent LOX metalloenzymes has a role in tumor metastasis and fibrotic diseases. In the formation of premetastatic niches, cancer cells secrete the LOX protein to stimulate collagen cross-linking and fibronectin synthesis [132]. This secretion promotes the migration and adhesion of tumor cells $[133,134]$. LOX promotes tumor cell migration and adhesion by activating the focal adhesion kinase (FAK1) [133]. To date, several dysregulations of enzymes from the LOX family were reported in breast, colorectal, prostate, gastric, hepatic, pancreatic, head, and neck cancers, and in skin cancers, including melanoma $[74,75,135]$. In bladder cancer, LOXL1 and LOXL4 inhibited oncogenic RAS-mediated activation of extracellular signal-regulated kinase (ERK), a tumor suppressive action leading to reduced colony formation [87]. Increased LOX levels may be associated with poor prognosis in different cancers, especially in patients with ER-negative breast cancers [136]. LOX proteins may play complex and paradoxical roles in the metastatic process or may act as tumor suppressors [135]. The mechanism by which copper is supplied to copper-dependent metalloenzymes LOX and LOX-likes (LOXL) is still not well known. A recent study in mice by Shanbhag, V. et al. has shown that the copper transporter ATP7A is necessary and sufficient for the activity of the enzymes LOX and LOXL. In addition, the silencing of ATP7A suppresses carcinogenesis via the loss of several mechanisms such as the loss of focal adhesion kinase (FAK1) phosphorylation and an attenuation of myeloid cell 
recruitment in the mouse lung. These observations open up opportunities for the development of new therapeutic strategies that could target ATP7A in order to act on the metalloenzymes of the LOX family responsible for metastasis formation [137].

\subsection{Role of Copper Metabolism in Drug Resistance}

Afterward, it was clearly established that certain proteins responsible for copper homeostasis also play a role in drug resistance and more specifically in resistance to platinum salt treatments.

In CRCs, an increase in the level of ATP7A mRNA was also found [57], and ATP7A may be a promising predictive biomarker of drug resistance in human CRCs [63]. In lung cancers, ATP7A protein is only expressed in $40 \%$ of tumor tissues, and patients expressing ATP7A had a poorer response to platinum-based chemotherapy. At the cellular level, both mRNA and protein levels of ATP7A were significantly higher in multidrug resistant A549 human lung adenocarcinoma cell lines when compared with the parental sensitive cells. ATP7A expression may thus be a predictive biomarker of chemoresistance and a negative prognostic factor for survival in non-small cell lung cancer (NSCLC) and ovarian cancer patients treated with platinum-based chemotherapy $[62,64,65]$.

The ATP7B protein is also deregulated in cancers. In CRCs, low mRNA or protein levels of ATP7B are associated with a response to oxaliplatin/5-FU treatment in patients [138]. ATP7B was also a predictive biomarker of platinum-based drug resistance in a NSCLC xenograft model [139] and in the clinical setting for CRCs [138], oral squamous carcinomas [69], and esophageal [66] and ovarian [140] carcinomas. In all of these clinical studies, ATP7B was not detected in the adjacent nonneoplastic tissues $[66,69,138,140]$. In addition, resistance to cisplatin was correlated with increased levels of GSH in ovarian tumor cell lines [141]. In various cancer types, the fluctuations of the total intracellular GSH level could explain the resistance/sensitivity patterns to cisplatin [142].

$\mathrm{Ctr1}$ is the major $\mathrm{Cu}$ influx carrier in human cells. Variations in Ctr1 expression were observed both in nonpathological tissues and in various cancer tissues. However, the absence of Ctr1 expression was also reported in some cancers such as cervical squamous carcinoma, prostate carcinoma, and gastric carcinoma [143]. The Ctr1 transporter is also responsible for the absorption of cisplatin, and Ctr1 is logically a key player in resistance and sensitivity mechanisms to platinum-based cancer therapies [144]. Other studies have shown a correlation between increased levels of Ctr1 and better absorption of platinum-based drugs in sensitive cells [109,145,146]. In addition, Ctr1 overexpression resulted in prolonged progression-free survival (PFS) and improved overall survival in patients with stage III NSCLC [107]. Many studies have hypothesized that the development of resistance to platinum-based drugs may be due to the defect in the glycosylation of the Ctr1 protein [147].

Finally, dysregulations of various $\mathrm{Cu}$ metabolic proteins can be the cause of resistance to platinum-based anticancer therapies [148]. These deregulations can be positive or negative depending on whether the protein is involved in the influx or efflux of $\mathrm{Cu}$, respectively. Consequently, the drug's ability to penetrate cells decreases [149]. This is due to the fact that platinum-based drugs use copper metabolism proteins to enter cells via Ctr1 initially [150], and subsequently bind to Atox1, which is responsible for intracellular copper trafficking [151,152]. Moreover, therapeutic platinum salts can be excreted outside the cells by the Cu transporters ATP7A or ATP7B $[153,154]$. This could explain the downregulation of Ctr1 to limit platinum cellular entry and the subsequent upregulation of ATP7A, ATP7B, and/or Atox1 to induce platinum excretion.

Moreover, copper consumption by growing cancer cells increases. Thus, it uses copper efflux proteins such as ATP7A/B to limit its potential toxicity and regulates its availability for oncogenic enzymes such as LOX and LOX-like proteins [155]. Numerous studies have concluded that the acquisition of resistance to platinum-based drugs is accompanied by an alteration in the absorption and efflux of copper [156-158]. These observations are not surprising because the platinum salt drugs interact with copper metabolism proteins [148]. To circumvent these resistance mechanisms against platinum complexes, drug screenings were performed to identify molecules able to maintain $\mathrm{Cu}$ transport to the Golgi apparatus while inhibiting platinum salt excretion [159]. 


\subsection{Implication of Copper Homeostasis Protein in the Proliferation and Growth of Cancer Cells}

Eventually, it turns out that the deregulation of copper metabolism has a role in cell proliferation and growth. We have previously seen that CCS delivers $\mathrm{Cu}$ to $\mathrm{Cu} / \mathrm{Zn}$ superoxide dismutase (SOD1). This $\mathrm{Cu}$ is mandatory for its maturation and its role in the control of reactive oxygen species production. Moreover, CCS could have the ability to promote carcinogenesis. The use of a specific inhibitor of CCS and Atox1 has been shown to reduce cancer cell proliferation and tumor growth. However, the potential presence of other targets that might work in synergy should not be excluded [160]. In patients with breast cancer, CCS protein level increases. The ability of CCS to promote proliferation may involve the MAPK/ERK pathway [161]. The expressions of CCS and COX17 are generally higher in lung cancer compared to healthy tissue. However, the expression of COX17 can vary between tumors and cell lines [162]. Another study showed that the upregulation of COX17 function and increased COX activity are also frequent features in lung carcinogenesis [125]. Overexpression of COX17 might also play a significant role in the oncogenesis of lung cancer. Moreover, in studies on human papillomavirus-positive head and neck squamous cell carcinomas, it has been observed that COX16 and COX17 expression was significantly correlated with the survival of the patient [126]. These observations suggest that the deregulation at the level of subunits and/or cofactors necessary for the assembly of cytochrome c oxidase could favor carcinogenesis.

Subsequently, studies have also shown deregulations of proteins of the superoxide dismutase family in some cancers [163]. These deregulations mainly result in decreased levels of SOD3 expression, and they are often associated with genetic alteration [163]. In breast cancer, the decrease in SOD3 mRNA expression levels is synonymous of poor prognosis [117,118]. In addition, studies have shown that overexpression of SOD3 can inhibit proliferation in vitro in various cancers [163]. Lastly, in cases of renal carcinomas, high SOD3 activity led to significant apoptosis [164]. These observations suggest that decreased mRNA levels of SOD confer a selective advantage to cancer cells. The majority of the studies have shown that this protein has a tumor suppressor role in many cancers [165]. Therefore, the deregulation of superoxide dismutase is an important player in oncogenesis.

Finally, recent studies have shown that autophagy has an important role in carcinogenesis. Autophagy is a cell degradation process that has an essential role in the development and differentiation of cells. Autophagy also constitutes a means of confronting intracellular and environmental stress, thus promoting tumor progression [166]. Recent research on autophagy has shown that Cu enhances the survival of cancer cells via the activation of autophagy. Indeed, $\mathrm{Cu}$ directly modulates the activity of the autophagic kinases ULK1 and ULK2. They described that a direct interaction between Cu and ULK1 is necessary and sufficient for autophagy signaling and induction [22]. Several studies have revealed the role of $\mathrm{Cu}$ in the induction of autophagy and the implication of this mechanism in carcinogenesis [22,167]. Consequently, these observations open up new therapeutic perspectives. To finish on cancer proliferation, correlations between GSH levels and cancer cell growth were found in melanoma and liver cancer $[113,168]$. In clear cell renal cell carcinoma, tumor progression and metastasis were linked to increased metabolic activity in both GSH and cysteine/methionine metabolism pathways [169].

\subsection{Deregulation of Other Copper-Dependent Proteins in Cancers}

In this section, we saw that the deregulations of homeostasis are multiple and these deregulations affect different stages of carcinogenesis. Nevertheless, several copper-dependent proteins are also affected by deregulation in the context of carcinogenesis, such as tyrosinase, whose expression is increased in melanoma [170].

Other dysregulations of copper-dependent proteins such as coagulation factors V and VIII have been found in different cancers [171-174]. Coagulation disorders have also been shown to occur in cancer patients. These disorders result in the constant activation of the coagulation system in the blood and malignant effusions [175]. However, it is important to note that no link between coagulation disorders and copper homeostasis dysregulation in cancers has been clearly demonstrated. 
To conclude, copper metabolism proteins and copper-dependent proteins are subject to numerous deregulations that can promote tumorigenesis. Therefore, these deregulations represent potential targets in the design of therapeutic strategies.

In the next part of this review, we will present different therapeutic strategies and lines of research based on the therapeutic use or the targeting of $\mathrm{Cu}$ and/or $\mathrm{Cu}$-proteins for cancer treatment.

\section{Copper as a Target or Bullet for Cancer Treatment}

\subsection{Copper Chelation-Based Treatment Strategies}

The use of chelators or ionophores is a frequent strategy to target $\mathrm{Cu}$ levels in cells [176]. Chelators directly bind and sequester metal ions, whereas ionophores cross cellular membranes in a Cu-bound form and release $\mathrm{Cu}$ on the other side of the membrane, generally leading to the increase of the intracellular concentrations of metal ions [177].

The first $\mathrm{Cu}$ chelators were developed in the mid-20th century for treating patients with Wilson's disease, notably D-penicillamine and trientine, which are acting extracellularly. More recently, $\mathrm{Cu}(\mathrm{I})$ chelators such as tetrathiomolybdate (TTM) have been developed to act inside cells in a more efficient way [21].

It has been shown that D-penicillamine induces inhibition of human endothelial cell proliferation in vitro and neovascularization in vivo [178]. Afterward, trientine also showed an antineoplastic effect and caused important suppression of tumor development in murine and human hepatocellular carcinoma cell lines $[179,180]$. Trientine is considered to have a reduced Cu chelating capacity compared to D-penicillamine, but it has a more tolerable toxicity profile.

In fact, the availability of cellular $\mathrm{Cu}$ is critical for the activity of MEK1 and MEK2 kinases in the RAS/MAPK signaling pathway. Copper intake promotes the phosphorylation of the MEK1 protein and ERK1 and ERK2 through a Cu-MEK1 interaction [181]. The activation of the copper-dependent mitogen-activated kinase (MAP) pathway is thus a key player in the promotion of tumor growth, and targeting $\mathrm{Cu}$ was proven to be a relevant strategy against cancer progression. In a cornerstone study, Brady et al. demonstrated the link between cancer mutational status and variations in cytosolic $\mathrm{Cu}$ content in melanoma [21]. The targeting of $\mathrm{Cu}$ with TTM induced antitumor effects in cells with BRAF V600E kinase mutations, which gave a strong rationale for the further development of several secondary studies aiming at disrupting the central role of $\mathrm{Cu}$ in other BRAF V600E-positive malignancies, such as thyroid, lung, and colorectal cancers or hairy cell leukemia [182].

The TTM chelator inhibited the growth of melanoma cell lines resistant to BRAF or MEK1/2 inhibitors and increased the antineoplastic activity of these inhibitors [183]. In addition, in CRC cells carrying BRAF V600E mutations, $\mathrm{Cu}$ depletion induced by pharmacological treatment with TTM reduced the growth of BRAF V600E cells in colon cancers that were resistant to BRAF inhibitors [184]. Currently, this chelator is evaluated as an adjuvant therapy in various cancer clinical trials.

Bleomycin (a glycopeptidic antibiotic produced by Streptomyces verticillus) and curcumin (a phytochemical agent) are other chelators that gave promising results in oncology $[185,186]$. Bleomycin is regularly used in combination with other therapeutic agents such as cisplatin and etoposide in testicular cancer [187]. Curcumin may be used in monotherapy or in combination with other anticancer agents potentially for the prevention of cancer [188].

Copper ionophores are molecules that transport $\mathrm{Cu}$ ions through cellular membranes. Ionophores increase and/or redistribute intracellular $\mathrm{Cu}$ levels, often allowing $\mathrm{Cu}$ to become bioavailable [176]. These molecules have a high affinity for $\mathrm{Cu}(\mathrm{II})$ and a low affinity for $\mathrm{Cu}(\mathrm{I})$. With the cytosol of the cells being a reducing environment, the $\mathrm{Cu}$ entering the cell will be reduced into its $\mathrm{Cu}(\mathrm{I})$ oxidation form. Such a release of $\mathrm{Cu}(\mathrm{I})$ will poison the cell [189].

In the family of ionophores, several compounds such as docosahexaenoic acid (DHA), disulfiram (DSF), bis (thiosemicarbazone) copper complexes, and clioquinol can be found. The clinical use of clioquinol has been discontinued because of its neurotoxicity [190], but clioquinol or its analogues 
are still tested in combination or with different administration routes to maintain its anticancer effects while reducing toxicities [191]. The anticancer efficacy of DSF was demonstrated in in vitro and in vivo models of inflammatory breast cancer [192], and DSF is currently tested in clinical trials (clinicaltrials.gov id\#: NCT04265274 and NCT03323346).

In addition, the combination of DSF and DHA has been shown to promote the death of cancer cells and to reduce the growth of cancer cells in vitro and in vivo [193]. One study has also suggested combining DSF with a PI3K inhibitor. This combination could be a new therapeutic strategy in breast cancer, particularly for patients with PIK3CA mutations [194]. In addition, coadministration of this drug with copper has shown inhibition of tumor growth in hormone-sensitive and castration-resistant models of the disease [195]. Finally, it has to be noticed that only the Cu-complexed form of these ionophores is active as a cancer treatment, i.e., disulfiram (DSF), bis (thiosemicarbazone) copper complexes, and clioquinol, because the ligands alone (metal-free compounds) have a minimal anticancer effect [196].

Some chelators such as curcumin or D-penicillamine penetrate cancer cells with difficulty because of their physicochemical properties. The development of innovative delivery systems for $\mathrm{Cu}$-chelating agents should overcome these limitations and increase their efficacy and limit potential side effects [197-199]. Other strategies such as photochemical internalization (PCI) have been used to improve the intracellular delivery of bleomycin [200].

\subsection{Copper-Based Nanoparticles and Metal-Based Strategies}

Copper-based nanoparticles (CuNPs) have theranostic applications in oncology, i.e., they can be used for imaging or therapeutic purposes [201]. CuNPs can be used in a variety of therapeutic strategies, such as photothermal therapy combined with immunotherapies, to induce systemic immune responses against tumors [202]. The photothermal activity of other CuNPs was successfully exploited to induce the destruction of residual cancer cells and prevent local cancer recurrence in vivo after a single irradiation session [203]. The development of transferrin-based CuNPs loaded with doxorubicin successfully inhibited in vivo tumor growth [204].

A long-lasting active research effort has shown that copper-based radioisotopes have a promising future in the field of cancer diagnostics and therapeutics, especially for the ${ }^{64}$ Cu isotope [205,206]. In a model of human CRC in hamsters, ${ }^{64} \mathrm{Cu}$ showed anticancer activity, and the survival was significantly increased [207]. Interestingly, the combination of the ${ }^{67} \mathrm{Cu}$ radioisotope with an anti-L1-cell adhesion molecule monoclonal antibody reduced the growth of human metastatic ovarian cancer cells [208].

Metal-based therapies are major players in oncology. In this field, copper-based complexes have a promising future as presented previously. For this reason, the alteration of $\mathrm{Cu}$ metabolism in cancer is the basis for the development of copper complexes with antineoplastic characteristics [209,210].

\subsection{Targeting Copper Metabolism Proteins}

Finally, several therapeutic strategies either using or targeting $\mathrm{Cu}$ metabolism or mimicking $\mathrm{Cu}$ protein metabolism are currently investigated. Some of these strategies focus on the properties of SOD to develop a redox approach. One of the approaches aims at producing excess ROS by exploiting the properties of certain metals, which will lead to the death of cancer cells [211,212]. Opposite strategies that focus on the elimination of the toxic free radical and its derivatives via SOD or SOD mimicking compounds have also been developed [213]. The combination of this therapeutic strategy with radiotherapy or chemotherapy has shown promising results in preclinical trials. This strategy is just one example of the many approaches developed around superoxide dismutase [163]. Afterward, in view of the involvement of LOX family metalloenzyme in tumorigenesis and the formation of metastases, strategies specifically targeting proteins of the LOX family have been developed. During LOX studies, LOX propeptide has been shown to have an inhibitory effect in the development of cancerous tumors [214]. Different approaches explored to test the inhibition of LOX through the 
development of inhibitors of LOX isoforms such as recombinant LOX propeptides or via the use of therapeutic antibodies targeting LOX and LOXL2 [214,215].

\section{Conclusions}

Currently, the importance of copper in carcinogenesis and metastasis formation and in resistance to treatment has been explored. In addition, research work on copper deregulation in oncology and the recent understanding of copper metabolism have led to the development of numerous therapeutic strategies targeting this trace element. Despite numerous research studies and the improvement of knowledge on copper metabolism over the years, some shadow areas persist. Specific alterations in $\mathrm{Cu}$ metabolism seem to have a promising future in the clinic as prognostic and/or predictive biomarkers. In the coming years, copper and its metabolism will continue to play a significant role in both cancer diagnosis and therapeutic strategy.

Author Contributions: P.L., A.D. and B.B. wrote the manuscript. A.D. and B.B. conceived the original idea. L.S. and J.-L.C. provided review and editing support. All authors have read and agreed to the published version of the manuscript.

Funding: Agence Nationale de la Recherche (ANR) with grant \# ANR-17-CE18-0028-01.

Conflicts of Interest: The authors declare no conflict of interest.

\section{References}

1. Turnlund, J.R.; Keyes, W.R.; Anderson, H.L.; Acord, L.L. Copper absorption and retention in young men at three levels of dietary copper by use of the stable isotope 65Cu. Am. J. Clin. Nutr. 1989, 49, 870-878. [CrossRef] [PubMed]

2. Linder, M.C. Ceruloplasmin and other copper binding components of blood plasma and their functions: An update. Metallomics 2016, 8, 887-905. [CrossRef] [PubMed]

3. Blockhuys, S.; Celauro, E.; Hildesjö, C.; Feizi, A.; Stål, O.; Fierro-González, J.C.; Wittung-Stafshede, P. Defining the human copper proteome and analysis of its expression variation in cancers. Metallomics 2017, 9, 112-123. [CrossRef]

4. Chen, G.F.; Sudhahar, V.; Youn, S.W.; Das, A.; Cho, J.; Kamiya, T.; Urao, N.; McKinney, R.D.; Surenkhuu, B.; Hamakubo, T.; et al. Copper Transport Protein Antioxidant-1 Promotes Inflammatory Neovascularization via Chaperone and Transcription Factor Function. Sci. Rep. 2015, 5, 14780. [CrossRef] [PubMed]

5. D'Ambrosi, N.; Rossi, L. Copper at synapse: Release, binding and modulation of neurotransmission. Neurochem. Int. 2015, 90, 36-45. [CrossRef] [PubMed]

6. Fukai, T.; Ushio-Fukai, M. Superoxide Dismutases: Role in Redox Signaling, Vascular Function, and Diseases. Antioxid. Redox Signal. 2011, 15, 1583-1606. [CrossRef] [PubMed]

7. Scheiber, I.; Dringen, R.; Mercer, J.F.B. Copper: Effects of Deficiency and Overload. In Interrelations between Essential Metal Ions and Human Diseases; Sigel, A., Sigel, H., Sigel, R.K.O., Eds.; Metal Ions in Life Sciences; Springer: Dordrecht, The Netherlands, 2013; Volume 13, pp. 359-387. ISBN 978-94-007-7499-5.

8. vandenBerghe, P.V.E.; Folmer, D.E.; Malingré, H.E.M.; vanBeurden, E.; Klomp, A.E.M.; vandeSluis, B.; Merkx, M.; Berger, R.; Klomp, L.W.J. Human copper transporter 2 is localized in late endosomes and lysosomes and facilitates cellular copper uptake. Biochem. J. 2007, 407, 49-59. [CrossRef] [PubMed]

9. Tsai, C.Y.; Liebig, J.K.; Tsigelny, I.F.; Howell, S.B. The copper transporter 1 (CTR1) is required to maintain the stability of copper transporter 2 (CTR2). Metallomics 2015, 7, 1477-1487. [CrossRef]

10. Öhrvik, H.; Nose, Y.; Wood, L.K.; Kim, B.E.; Gleber, S.C.; Ralle, M.; Thiele, D.J. Ctr2 regulates biogenesis of a cleaved form of mammalian Ctr1 metal transporter lacking the copper- and cisplatin-binding ecto-domain. Proc. Natl. Acad. Sci. USA 2013, 110, E4279-E4288. [CrossRef]

11. Kamiya, T.; Takeuchi, K.; Fukudome, S.; Hara, H.; Adachi, T. Copper chaperone antioxidant-1, Atox-1, is involved in the induction of SOD3 in THP-1 cells. BioMetals 2018, 31, 61-68. [CrossRef]

12. Panchenko, M.V.; Stetler-Stevenson, W.G.; Trubetskoy, O.V.; Gacheru, S.N.; Kagan, H.M. Metalloproteinase activity secreted by fibrogenic cells in the processing of prolysyl oxidase. Potential role of procollagen C-proteinase. J. Biol. Chem. 1996, 271, 7113-7119. [CrossRef] [PubMed] 
13. Trackman, P.C.; Bedell-Hogan, D.; Tang, J.; Kagan, H.M. Post-translational glycosylation and proteolytic processing of a lysyl oxidase precursor. J. Biol. Chem. 1992, 267, 8666-8671. [PubMed]

14. Lai, X.; Wichers, H.J.; Soler-Lopez, M.; Dijkstra, B.W. Structure and Function of Human Tyrosinase and Tyrosinase-Related Proteins. Chem. Eur. J. 2018, 24, 47-55. [CrossRef]

15. Scheiber, I.F.; Brůha, R.; Dušek, P. Pathogenesis of Wilson disease. In Handbook of Clinical Neurology; Elsevier: Amsterdam, The Netherlands, 2017; Volume 142, pp. 43-55. ISBN 978-0-444-63625-6.

16. Linder, M.C.; Hazegh-Azam, M. Copper biochemistry and molecular biology. Am. J. Clin. Nutr. 1996, 63, 797S-811S. [CrossRef] [PubMed]

17. Vashchenko, G.; MacGillivray, R. Multi-Copper Oxidases and Human Iron Metabolism. Nutrients 2013, 5, 2289-2313. [CrossRef] [PubMed]

18. Harris, Z.L.; Durley, A.P.; Man, T.K.; Gitlin, J.D. Targeted gene disruption reveals an essential role for ceruloplasmin in cellular iron efflux. Proc. Natl. Acad. Sci. USA 1999, 96, 10812-10817. [CrossRef]

19. Turski, M.L.; Thiele, D.J. New Roles for Copper Metabolism in Cell Proliferation, Signaling, and Disease. J. Biol. Chem. 2009, 284, 717-721. [CrossRef]

20. Członkowska, A.; Litwin, T.; Dusek, P.; Ferenci, P.; Lutsenko, S.; Medici, V.; Rybakowski, J.K.; Weiss, K.H.; Schilsky, M.L. Wilson disease. Nat. Rev. Dis. Primer 2018, 4, 21. [CrossRef]

21. Brady, D.C.; Crowe, M.S.; Turski, M.L.; Hobbs, G.A.; Yao, X.; Chaikuad, A.; Knapp, S.; Xiao, K.; Campbell, S.L.; Thiele, D.J.; et al. Copper is required for oncogenic BRAF signalling and tumorigenesis. Nature 2014, 509, 492-496. [CrossRef]

22. Tsang, T.; Posimo, J.M.; Gudiel, A.A.; Cicchini, M.; Feldser, D.M.; Brady, D.C. Copper is an essential regulator of the autophagic kinases ULK1/2 to drive lung adenocarcinoma. Nat. Cell Biol. 2020, 22, 412-424. [CrossRef]

23. Grubman, A.; White, A.R. Copper as a key regulator of cell signalling pathways. Expert Rev. Mol. Med. 2014, 16, e11. [CrossRef] [PubMed]

24. Baker, Z.N.; Cobine, P.A.; Leary, S.C. The mitochondrion: A central architect of copper homeostasis. Met. Integr. Biometal Sci. 2017, 9, 1501-1512. [CrossRef] [PubMed]

25. Timón-Gómez, A.; Nývltová, E.; Abriata, L.A.; Vila, A.J.; Hosler, J.; Barrientos, A. Mitochondrial cytochrome c oxidase biogenesis: Recent developments. Semin. Cell Dev. Biol. 2018, 76, 163-178. [CrossRef] [PubMed]

26. Cobine, P.A.; Pierrel, F.; Bestwick, M.L.; Winge, D.R. Mitochondrial Matrix Copper Complex Used in Metallation of Cytochrome Oxidase and Superoxide Dismutase. J. Biol. Chem. 2006, 281, 36552-36559. [CrossRef]

27. Boulet, A.; Vest, K.E.; Maynard, M.K.; Gammon, M.G.; Russell, A.C.; Mathews, A.T.; Cole, S.E.; Zhu, X.; Phillips, C.B.; Kwong, J.Q.; et al. The mammalian phosphate carrier SLC25A3 is a mitochondrial copper transporter required for cytochrome c oxidase biogenesis. J. Biol. Chem. 2018, 293, 1887-1896. [CrossRef]

28. Zischka, H.; Einer, C. Mitochondrial copper homeostasis and its derailment in Wilson disease. Int. J. Biochem. Cell Biol. 2018, 102, 71-75. [CrossRef]

29. Polishchuk, E.V.; Polishchuk, R.S. The emerging role of lysosomes in copper homeostasis. Met. Integr. Biometal Sci. 2016, 8, 853-862. [CrossRef]

30. Polishchuk, E.V.; Concilli, M.; Iacobacci, S.; Chesi, G.; Pastore, N.; Piccolo, P.; Paladino, S.; Baldantoni, D.; van IJzendoorn, S.C.D.; Chan, J.; et al. Wilson Disease Protein ATP7B Utilizes Lysosomal Exocytosis to Maintain Copper Homeostasis. Dev. Cell 2014, 29, 686-700. [CrossRef]

31. Ohgami, R.S.; Campagna, D.R.; McDonald, A.; Fleming, M.D. The Steap proteins are metalloreductases. Blood 2006, 108, 1388-1394. [CrossRef]

32. Gomes, I.M.; Maia, C.J.; Santos, C.R. STEAP Proteins: From Structure to Applications in Cancer Therapy. Mol. Cancer Res. 2012, 10, 573-587. [CrossRef]

33. Si, M.; Lang, J. The roles of metallothioneins in carcinogenesis. J. Hematol. Oncol. 2018, 11, 107. [CrossRef] [PubMed]

34. Aquilano, K.; Baldelli, S.; Ciriolo, M.R. Glutathione: New roles in redox signaling for an old antioxidant. Front. Pharmacol. 2014, 5, 196. [CrossRef] [PubMed]

35. Kardos, J.; Héja, L.; Simon, Á.; Jablonkai, I.; Kovács, R.; Jemnitz, K. Copper signalling: Causes and consequences. Cell Commun. Signal. 2018, 16, 71. [CrossRef] [PubMed]

36. Maryon, E.B.; Molloy, S.A.; Kaplan, J.H. Cellular glutathione plays a key role in copper uptake mediated by human copper transporter 1. Am. J. Physiol. Cell Physiol. 2013, 304, C768-C779. [CrossRef] [PubMed] 
37. Morgan, M.T.; Bourassa, D.; Harankhedkar, S.; McCallum, A.M.; Zlatic, S.A.; Calvo, J.S.; Meloni, G.; Faundez, V.; Fahrni, C.J. Ratiometric two-photon microscopy reveals attomolar copper buffering in normal and Menkes mutant cells. Proc. Natl. Acad. Sci. USA 2019, 116, 12167-12172. [CrossRef]

38. Guo, C.H.; Chen, P.C.; Yeh, M.S.; Hsiung, D.Y.; Wang, C.L. Cu/Zn ratios are associated with nutritional status, oxidative stress, inflammation, and immune abnormalities in patients on peritoneal dialysis. Clin. Biochem. 2011, 44, 275-280. [CrossRef] [PubMed]

39. Mezzetti, A.; Pierdomenico, S.D.; Costantini, F.; Romano, F.; De Cesare, D.; Cuccurullo, F.; Imbastaro, T.; Riario-Sforza, G.; Di Giacomo, F.; Zuliani, G.; et al. Copper/zinc ratio and systemic oxidant load: Effect of aging and aging-related degenerative diseases. Free Radic. Biol. Med. 1998, 25, 676-681. [CrossRef]

40. Mao, S.; Huang, S. Zinc and Copper Levels in Bladder Cancer: A Systematic Review and Meta-Analysis. Biol. Trace Elem. Res. 2013, 153, 5-10. [CrossRef]

41. Juloski, J.T.; Rakic, A.; Ćuk, V.V.; Ćuk, V.M.; Stefanović, S.; Nikolić, D.; Janković, S.; Trbovich, A.M.; De Luka, S.R. Colorectal cancer and trace elements alteration. J. Trace Elem. Med. Biol. 2020, 59, 126451. [CrossRef]

42. Zowczak, M.; Iskra, M.; Torliński, L.; Cofta, S. Analysis of Serum Copper and Zinc Concentrations in Cancer Patients. Biol. Trace Elem. Res. 2001, 82, 001-008. [CrossRef]

43. Saleh, S.A.K.; Adly, H.M.; Abdelkhaliq, A.A.; Nassir, A.M. Serum Levels of Selenium, Zinc, Copper, Manganese, and Iron in Prostate Cancer Patients. Curr. Urol. 2020, 14, 44-49. [CrossRef] [PubMed]

44. Yücel, I.; Arpaci, F.; Özet, A.; Döner, B.; Karayilanoĝlu, T.; Sayar, A.; Berk, Ö. Serum copper and zinc levels and copper/zinc ratio in patients with breast cancer. Biol. Trace Elem. Res. 1994, 40, 31-38. [CrossRef] [PubMed]

45. Khoshdel, Z.; Naghibalhossaini, F.; Abdollahi, K.; Shojaei, S.; Moradi, M.; Malekzadeh, M. Serum Copper and Zinc Levels Among Iranian Colorectal Cancer Patients. Biol. Trace Elem. Res. 2016, 170, 294-299. [CrossRef]

46. Fabris, C.; Farini, R.; Del Favero, G.; Gurrieri, G.; Piccoli, A.; Sturniolo, G.C.; Panucci, A.; Naccarato, R. Copper, zinc and copper/zinc ratio in chronic pancreatitis and pancreatic cancer. Clin. Biochem. 1985, 18, 373-375. [CrossRef]

47. Cunzhi, H.; Jiexian, J.; Xianwen, Z.; Jingang, G.; Shumin, Z.; Lili, D. Serum and Tissue Levels of Six Trace Elements and Copper/Zinc Ratio in Patients with Cervical Cancer and Uterine Myoma. Biol. Trace Elem. Res. 2003, 94, 113-122. [CrossRef]

48. Kucharzewski, M.; Braziewicz, J.; Majewska, U.; Gózdz, S. Selenium, Copper, and Zinc Concentrations in Intestinal Cancer Tissue and in Colon and Rectum Polyps. Biol. Trace Elem. Res. 2003, 92, 1-10. [CrossRef]

49. Jouybari, L.; Kiani, F.; Islami, F.; Sanagoo, A.; Sayehmiri, F.; Hosnedlova, B.; Doşa, M.D.; Kizek, R.; Chirumbolo, S.; Bjørklund, G. Copper Concentrations in Breast Cancer: A Systematic Review and Meta-Analysis. Curr. Med. Chem. 2019, 26. [CrossRef]

50. Lavilla, I.; Costas, M.; Miguel, P.S.; Millos, J.; Bendicho, C. Elemental fingerprinting of tumorous and adjacent non-tumorous tissues from patients with colorectal cancer using ICP-MS, ICP-OES and chemometric analysis. BioMetals 2009, 22, 863-875. [CrossRef]

51. Díez, M.; Arroyo, M.; Cerdàn, F.J.; Muñoz, M.; Martin, M.A.; Balibrea, J.L. Serum and Tissue Trace Metal Levels in Lung Cancer. Oncology 1989, 46, 230-234. [CrossRef]

52. Yoshida, D.; Ikeda, Y.; Nakazawa, S. Quantitative analysis of copper, zinc and copper/zinc ratio in selected human brain tumors. J. Neurooncol. 1993, 16, 109-115. [CrossRef]

53. Callejón-Leblic, B.; Gómez-Ariza, J.L.; Pereira-Vega, A.; García-Barrera, T. Metal dyshomeostasis based biomarkers of lung cancer using human biofluids. Metallomics 2018, 10, 1444-1451. [CrossRef] [PubMed]

54. Blockhuys, S.; Malmberg, P.; Wittung-Stafshede, P. Copper distribution in breast cancer cells detected by time-of-flight secondary ion mass spectrometry with delayed extraction methodology. Biointerphases 2018, 13, E412. [CrossRef] [PubMed]

55. Majumder, S.; Chatterjee, S.; Pal, S.; Biswas, J.; Efferth, T.; Choudhuri, S.K. The role of copper in drug-resistant murine and human tumors. BioMetals 2009, 22, 377-384. [CrossRef] [PubMed]

56. Télouk, P.; Puisieux, A.; Fujii, T.; Balter, V.; Bondanese, V.P.; Morel, A.P.; Clapisson, G.; Lamboux, A.; Albarede, F. Copper isotope effect in serum of cancer patients. A pilot study. Metallomics 2015, 7, 299-308. [CrossRef] 
57. Barresi, V.; Trovato-Salinaro, A.; Spampinato, G.; Musso, N.; Castorina, S.; Rizzarelli, E.; Condorelli, D.F. Transcriptome analysis of copper homeostasis genes reveals coordinated upregulation of SLC31A1, SCO 1, and COX11 in colorectal cancer. FEBS Open Bio. 2016, 6, 794-806. [CrossRef]

58. Kim, Y.J.; Bond, G.J.; Tsang, T.; Posimo, J.M.; Busino, L.; Brady, D.C. Copper chaperone ATOX1 is required for MAPK signaling and growth in BRAF mutation-positive melanoma. Metallomics 2019, 11, 1430-1440. [CrossRef]

59. Jana, A.; Das, A.; Krett, N.L.; Guzman, G.; Thomas, A.; Mancinelli, G.; Bauer, J.; Ushio-Fukai, M.; Fukai, T.; Jung, B. Nuclear translocation of Atox1 potentiates activin A-induced cell migration and colony formation in colon cancer. PLoS ONE 2020, 15, e0227916. [CrossRef]

60. Crnogorac-Jurcevic, T.; Gangeswaran, R.; Bhakta, V.; Capurso, G.; Lattimore, S.; Akada, M.; Sunamura, M.; Prime, W.; Campbell, F.; Brentnall, T.A.; et al. Proteomic Analysis of Chronic Pancreatitis and Pancreatic Adenocarcinoma. Gastroenterology 2005, 129, 1454-1463. [CrossRef]

61. Györffy, B.; Lanczky, A.; Eklund, A.C.; Denkert, C.; Budczies, J.; Li, Q.; Szallasi, Z. An online survival analysis tool to rapidly assess the effect of 22,277 genes on breast cancer prognosis using microarray data of 1809 patients. Breast Cancer Res. Treat. 2010, 123, 725-731. [CrossRef]

62. Li, Z.; Qiu, M.; Zeng, Z.; Luo, H.; Wu, W.; Wang, F.; Wang, Z.; Zhang, D.; Li, Y.; Xu, R. Copper-transporting P-type adenosine triphosphatase (ATP7A) is associated with platinum-resistance in non-small cell lung cancer (NSCLC). J. Transl. Med. 2012, 10, 21. [CrossRef]

63. Owatari, S.; Akune, S.; Komatsu, M.; Ikeda, R.; Firth, S.D.; Che, X.F.; Yamamoto, M.; Tsujikawa, K.; Kitazono, M.; Ishizawa, T.; et al. Copper-Transporting P-Type ATPase, ATP7A, Confers Multidrug Resistance and Its Expression Is Related to Resistance to SN-38 in Clinical Colon Cancer. Cancer Res. 2007, 67, 4860-4868. [CrossRef] [PubMed]

64. Samimi, G.; Safaei, R.; Katano, K.; Holzer, A.K.; Rochdi, M.; Tomioka, M.; Goodman, M.; Howell, S.B. Increased expression of the copper efflux transporter ATP7A mediates resistance to cisplatin, carboplatin, and oxaliplatin in ovarian cancer cells. Clin. Cancer Res. Off. J. Am. Assoc. Cancer Res. 2004, 10, 4661-4669. [CrossRef] [PubMed]

65. Samimi, G.; Varki, N.M.; Wilczynski, S.; Safaei, R.; Alberts, D.S.; Howell, S.B. Increase in expression of the copper transporter ATP7A during platinum drug-based treatment is associated with poor survival in ovarian cancer patients. Clin. Cancer Res. 2003, 9, 5853-5859. [PubMed]

66. Higashimoto, M.; Kanzaki, A.; Shimakawa, T.; Konno, S.; Naritaka, Y.; Nitta, Y.; Mori, S.; Shirata, S.; Yoshida, A.; Terada, K.; et al. Expression of copper-transporting P-type adenosine triphosphatase in human esophageal carcinoma. Int. J. Mol. Med. 2003, 11, 337-341. [CrossRef]

67. Aida, T.; Takebayashi, Y.; Shimizu, T.; Okamura, C.; Higasimoto, M.; Kanzaki, A.; Nakayama, K.; Terada, K.; Sugiyama, T.; Miyazaki, K.; et al. Expression of copper-transporting P-type adenosine triphosphatase (ATP7B) as a prognostic factor in human endometrial carcinoma. Gynecol. Oncol. 2005, 97, 41-45. [CrossRef]

68. Kanzaki, A.; Toi, M.; Neamati, N.; Miyashita, H.; Oubu, M.; Nakayama, K.; Bando, H.; Ogawa, K.; Mutoh, M.; Mori, S.; et al. Copper-transporting P-Type Adenosine Triphosphatase (ATP7B) Is Expressed in Human Breast Carcinoma. Jpn. J. Cancer Res. 2002, 93, 70-77. [CrossRef]

69. Miyashita, H.; Nitta, Y.; Mori, S.; Kanzaki, A.; Nakayama, K.; Terada, K.; Sugiyama, T.; Kawamura, H.; Sato, A.; Morikawa, H.; et al. Expression of copper-transporting P-type adenosine triphosphatase (ATP7B) as a chemoresistance marker in human oral squamous cell carcinoma treated with cisplatin. Oral Oncol. 2003, 39, 157-162. [CrossRef]

70. Ohbu, M.; Ogawa, K.; Konno, S.; Kanzaki, A.; Terada, K.; Sugiyama, T.; Takebayashi, Y. Copper-transporting P-type adenosine triphosphatase (ATP7B) is expressed in human gastric carcinoma. Cancer Lett. 2003, 189, 33-38. [CrossRef]

71. Sugeno, H.; Takebayashi, Y.; Higashimoto, M.; Ogura, Y.; Shibukawa, G.; Kanzaki, A.; Terada, K.; Sugiyama, T.; Watanabe, K.; Katoh, R.; et al. Expression of copper-transporting P-type adenosine triphosphatase (ATP7B) in human hepatocellular carcinoma. Anticancer Res. 2004, 24, 1045-1048.

72. Zhang, J.; Zhang, L.; Li, C.; Yang, C.; Li, L.; Song, S.; Wu, H.; Liu, F.; Wang, L.; Gu, J. LOX-1 is a poor prognostic indicator and induces epithelial-mesenchymal transition and metastasis in pancreatic cancer patients. Cell. Oncol. 2018, 41, 73-84. [CrossRef] 
73. González-Chavarría, I.; Fernandez, E.; Gutierrez, N.; González-Horta, E.E.; Sandoval, F.; Cifuentes, P.; Castillo, C.; Cerro, R.; Sanchez, O.; Toledo, J.R. LOX-1 activation by oxLDL triggers an epithelial mesenchymal transition and promotes tumorigenic potential in prostate cancer cells. Cancer Lett. 2018, 414,34-43. [CrossRef] [PubMed]

74. Baker, A.M.; Cox, T.R.; Bird, D.; Lang, G.; Murray, G.I.; Sun, X.F.; Southall, S.M.; Wilson, J.R.; Erler, J.T. The Role of Lysyl Oxidase in SRC-Dependent Proliferation and Metastasis of Colorectal Cancer. J. Natl. Cancer Inst. 2011, 103, 407-424. [CrossRef] [PubMed]

75. Wong, C.C.L.; Tse, A.P.W.; Huang, Y.P.; Zhu, Y.T.; Chiu, D.K.C.; Lai, R.K.H.; Au, S.L.K.; Kai, A.K.L.; Lee, J.M.F.; Wei, L.L.; et al. Lysyl oxidase-like 2 is critical to tumor microenvironment and metastatic niche formation in hepatocellular carcinoma. Hepatology 2014, 60, 1645-1658. [CrossRef] [PubMed]

76. Kirschmann, D.A.; Seftor, E.A.; Fong, S.F.T.; Nieva, D.R.C.; Sullivan, C.M.; Edwards, E.M.; Sommer, P.; Csiszar, K.; Hendrix, M.J.C. A molecular role for lysyl oxidase in breast cancer invasion. Cancer Res. 2002, 62, 4478-4483.

77. Erler, J.T.; Bennewith, K.L.; Cox, T.R.; Lang, G.; Bird, D.; Koong, A.; Le, Q.T.; Giaccia, A.J. Hypoxia-Induced Lysyl Oxidase Is a Critical Mediator of Bone Marrow Cell Recruitment to Form the Premetastatic Niche. Cancer Cell 2009, 15, 35-44. [CrossRef]

78. Postovit, L.M.; Abbott, D.E.; Payne, S.L.; Wheaton, W.W.; Margaryan, N.V.; Sullivan, R.; Jansen, M.K.; Csiszar, K.; Hendrix, M.J.C.; Kirschmann, D.A. Hypoxia/reoxygenation: A dynamic regulator of lysyl oxidase-facilitated breast cancer migration. J. Cell. Biochem. 2008, 103, 1369-1378. [CrossRef]

79. Woznick, A.R.; Braddock, A.L.; Dulai, M.; Seymour, M.L.; Callahan, R.E.; Welsh, R.J.; Chmielewski, G.W.; Zelenock, G.B.; Shanley, C.J. Lysyl oxidase expression in bronchogenic carcinoma. Am. J. Surg. 2005, 189, 297-301. [CrossRef]

80. Kaneda, A.; Wakazono, K.; Tsukamoto, T.; Watanabe, N.; Yagi, Y.; Tatematsu, M.; Kaminishi, M.; Sugimura, T.; Ushijima, T. Lysyl Oxidase Is a Tumor Suppressor Gene Inactivated by Methylation and Loss of Heterozygosity in Human Gastric Cancers. Cancer Res. 2004, 64, 6410-6415. [CrossRef]

81. Le, Q.T.; Harris, J.; Magliocco, A.M.; Kong, C.S.; Diaz, R.; Shin, B.; Cao, H.; Trotti, A.; Erler, J.T.; Chung, C.H.; et al. Validation of Lysyl Oxidase As a Prognostic Marker for Metastasis and Survival in Head and Neck Squamous Cell Carcinoma: Radiation Therapy Oncology Group Trial 90-03. J. Clin. Oncol. 2009, 27, 4281-4286. [CrossRef]

82. Gao, Y.; Xiao, Q.; Ma, H.; Li, L.; Liu, J.; Feng, Y.; Fang, Z.; Wu, J.; Han, X.; Zhang, J.; et al. LKB1 inhibits lung cancer progression through lysyl oxidase and extracellular matrix remodeling. Proc. Natl. Acad. Sci. USA 2010, 107, 18892-18897. [CrossRef]

83. Wilgus, M.L.; Borczuk, A.C.; Stoopler, M.; Ginsburg, M.; Gorenstein, L.; Sonett, J.R.; Powell, C.A. Lysyl oxidase: A lung adenocarcinoma biomarker of invasion and survival. Cancer 2011, 117, 2186-2191. [CrossRef] [PubMed]

84. Albinger-Hegyi, A.; Stoeckli, S.J.; Schmid, S.; Storz, M.; Iotzova, G.; Probst-Hensch, N.M.; Rehrauer, H.; Tinguely, M.; Moch, H.; Hegyi, I. Lysyl oxidase expression is an independent marker of prognosis and a predictor of lymph node metastasis in oral and oropharyngeal squamous cell carcinoma (OSCC). Int. J. Cancer 2010. [CrossRef]

85. Bouez, C. The Lysyl Oxidase LOX Is Absent in Basal and Squamous Cell Carcinomas and Its Knockdown Induces an Invading Phenotype in a Skin Equivalent Model. Clin. Cancer Res. 2006, 12, 1463-1469. [CrossRef] [PubMed]

86. Stassar, M.J.J.G.; Devitt, G.; Brosius, M.; Rinnab, L.; Prang, J.; Schradin, T.; Simon, J.; Petersen, S.; Kopp-Schneider, A.; Zöller, M. Identification of human renal cell carcinoma associated genes by suppression subtractive hybridization. Br. J. Cancer 2001, 85, 1372-1382. [CrossRef] [PubMed]

87. Wu, G.; Guo, Z.; Chang, X.; Kim, M.S.; Nagpal, J.K.; Liu, J.; Maki, J.M.; Kivirikko, K.I.; Ethier, S.P.; Trink, B.; et al. LOXL1 and LOXL4 Are Epigenetically Silenced and Can Inhibit Ras/Extracellular Signal-Regulated Kinase Signaling Pathway in Human Bladder Cancer. Cancer Res. 2007, 67, 4123-4129. [CrossRef] [PubMed]

88. Ji, H.; Ramsey, M.R.; Hayes, D.N.; Fan, C.; McNamara, K.; Kozlowski, P.; Torrice, C.; Wu, M.C.; Shimamura, T.; Perera, S.A.; et al. LKB1 modulates lung cancer differentiation and metastasis. Nature 2007, 448, 807-810. [CrossRef]

89. Bell, A.; Bell, D.; Weber, R.S.; El-Naggar, A.K. CpG island methylation profiling in human salivary gland adenoid cystic carcinoma. Cancer 2011, 117, 2898-2909. [CrossRef] 
90. Peinado, H.; Moreno-Bueno, G.; Hardisson, D.; Perez-Gomez, E.; Santos, V.; Mendiola, M.; de Diego, J.I.; Nistal, M.; Quintanilla, M.; Portillo, F.; et al. Lysyl Oxidase-Like 2 as a New Poor Prognosis Marker of Squamous Cell Carcinomas. Cancer Res. 2008, 68, 4541-4550. [CrossRef]

91. Moreno-Bueno, G.; Salvador, F.; Martín, A.; Floristán, A.; Cuevas, E.P.; Santos, V.; Montes, A.; Morales, S.; Castilla, M.A.; Rojo-Sebastián, A.; et al. Lysyl oxidase-like 2 (LOXL2), a new regulator of cell polarity required for metastatic dissemination of basal-like breast carcinomas. EMBO Mol. Med. 2011, 3, 528-544. [CrossRef]

92. Hollosi, P.; Yakushiji, J.K.; Fong, K.S.K.; Csiszar, K.; Fong, S.F.T. Lysyl oxidase-like 2 promotes migration in noninvasive breast cancer cells but not in normal breast epithelial cells. Int. J. Cancer 2009, 125, 318-327. [CrossRef]

93. Brekhman, V.; Lugassie, J.; Zaffryar-Eilot, S.; Sabo, E.; Kessler, O.; Smith, V.; Golding, H.; Neufeld, G. Receptor activity modifying protein-3 mediates the protumorigenic activity of lysyl oxidase-like protein-2. FASEB J. 2011, 25, 55-65. [CrossRef] [PubMed]

94. Barry-Hamilton, V.; Spangler, R.; Marshall, D.; McCauley, S.; Rodriguez, H.M.; Oyasu, M.; Mikels, A.; Vaysberg, M.; Ghermazien, H.; Wai, C.; et al. Allosteric inhibition of lysyl oxidase-like-2 impedes the development of a pathologic microenvironment. Nat. Med. 2010, 16, 1009-1017. [CrossRef] [PubMed]

95. Kim Differential expression of the LOX family genes in human colorectal adenocarcinomas. Oncol. Rep. 2009, 22. [CrossRef]

96. Offenberg, H.; Brünner, N.; Mansilla, F.; Ørntoft Torben, F.; Birkenkamp-Demtroder, K. TIMP-1 expression in human colorectal cancer is associated with TGF-B1, LOXL2, INHBA1, TNF-AIP6 and TIMP-2 transcript profiles. Mol. Oncol. 2008, 2, 233-240. [CrossRef]

97. Macartney-Coxson, D.P.; Hood, K.A.; Shi, H.; Ward, T.; Wiles, A.; O'Connor, R.; Hall, D.A.; Lea, R.A.; Royds, J.A.; Stubbs, R.S.; et al. Metastatic susceptibility locus, an 8p hot-spot for tumour progression disrupted in colorectal liver metastases: 13 candidate genes examined at the DNA, mRNA and protein level. BMC Cancer 2008, 8, 187. [CrossRef]

98. Peng, L.; Ran, Y.L.; Hu, H.; Yu, L.; Liu, Q.; Zhou, Z.; Sun, Y.M.; Sun, L.C.; Pan, J.; Sun, L.X.; et al. Secreted LOXL2 is a novel therapeutic target that promotes gastric cancer metastasis via the Src/FAK pathway. Carcinogenesis 2009, 30, 1660-1669. [CrossRef]

99. Zhan, P.; Shen, X.; Qian, Q.; Zhu, J.; Zhang, Y.; Xie, H.Y.; Xu, C.H.; Hao, K.; Hu, W.; Xia, N.; et al. Down-regulation of lysyl oxidase-like 2 (LOXL2) is associated with disease progression in lung adenocarcinomas. Med. Oncol. 2012, 29, 648-655. [CrossRef]

100. Rückert, F.; Joensson, P.; Saeger, H.D.; Grützmann, R.; Pilarsky, C. Functional analysis of LOXL2 in pancreatic carcinoma. Int. J. Colorectal Dis. 2010, 25, 303-311. [CrossRef]

101. Schmidt, H.; Semjonow, A.; Csiszar, K.; Korsching, E.; Brandt, B.; Eltze, E. Mapping of a deletion interval on 8p21-22 in prostate cancer by gene dosage PCR. Verh. Dtsch. Ges. Pathol. 2007, 91, 302-307.

102. Sano, M.; Aoyagi, K.; Takahashi, H.; Kawamura, T.; Mabuchi, T.; Igaki, H.; Tachimori, Y.; Kato, H.; Ochiai, A.; Honda, H.; et al. Forkhead box A1 transcriptional pathway in KRT7-expressing esophageal squamous cell carcinomas with extensive lymph node metastasis. Int. J. Oncol. 2010, 36, 321-330. [CrossRef]

103. Peinado, H.; del Carmen Iglesias-de la Cruz, M.; Olmeda, D.; Csiszar, K.; Fong, K.S.K.; Vega, S.; Nieto, M.A.; Cano, A.; Portillo, F. A molecular role for lysyl oxidase-like 2 enzyme in Snail regulation and tumor progression. EMBO J. 2005, 24, 3446-3458. [CrossRef]

104. Scola, N.; Görögh, T. LOXL4 as a selective molecular marker in primary and metastatic head/neck carcinoma. Anticancer Res. 2010, 30, 4567-4571. [PubMed]

105. Holtmeier, C.; Görögh, T.; Beier, U.; Meyer, J.; Hoffmann, M.; Gottschlich, S.; Heidorn, K.; Ambrosch, P.; Maune, S. Overexpression of a novel lysyl oxidase-like gene in human head and neck squamous cell carcinomas. Anticancer Res. 2003, 23, 2585-2591. [PubMed]

106. Weise, J.B.; Csiszar, K.; Gottschlich, S.; Hoffmann, M.; Schmidt, A.; Weingartz, U.; Adamzik, I.; Heiser, A.; Kabelitz, D.; Ambrosch, P.; et al. Vaccination strategy to target lysyl oxidase-like 4 in dendritic cell based immunotherapy for head and neck cancer. Int. J. Oncol. 2008, 32, 317-322. [CrossRef]

107. Chen, H.H.W.; Yan, J.J.; Chen, W.C.; Kuo, M.T.; Lai, Y.H.; Lai, W.W.; Liu, H.S.; Su, W.C. Predictive and prognostic value of human copper transporter 1 (hCtr1) in patients with stage III non-small-cell lung cancer receiving first-line platinum-based doublet chemotherapy. Lung Cancer 2012, 75, 228-234. [CrossRef] [PubMed] 
108. Lee, Y.Y.; Choi, C.H.; Do, I.G.; Song, S.Y.; Lee, W.; Park, H.S.; Song, T.J.; Kim, M.K.; Kim, T.J.; Lee, J.W.; et al. Prognostic value of the copper transporters, CTR1 and CTR2, in patients with ovarian carcinoma receiving platinum-based chemotherapy. Gynecol. Oncol. 2011, 122, 361-365. [CrossRef] [PubMed]

109. Holzer, A.K.; Samimi, G.; Katano, K.; Naerdemann, W.; Lin, X.; Safaei, R.; Howell, S.B. The Copper Influx Transporter Human Copper Transport Protein 1 Regulates the Uptake of Cisplatin in Human Ovarian Carcinoma Cells. Mol. Pharmacol. 2004, 66, 817-823. [CrossRef] [PubMed]

110. Adeoti, M.; Oguntola, A.; Akanni, E.; Agodirin, O.; Oyeyemi, G. Trace elements; copper, zinc and selenium, in breast cancer afflicted female patients in LAUTECH Osogbo, Nigeria. Indian J. Cancer 2015, 52, 106. [CrossRef]

111. Dragutinović, V.V.; Tatić, S.B.; Nikolić-Mandić, S.D.; Tripković, T.M.; Dunđerović, D.M.; Paunović, I.R. Copper as Ancillary Diagnostic Tool in Preoperative Evaluation of Possible Papillary Thyroid Carcinoma in Patients with Benign Thyroid Disease. Biol. Trace Elem. Res. 2014, 160, 311-315. [CrossRef]

112. Atakul, T.; Altinkaya, S.O.; Abas, B.I.; Yenisey, C. Serum Copper and Zinc Levels in Patients with Endometrial Cancer. Biol. Trace Elem. Res. 2020, 195, 46-54. [CrossRef]

113. Huang, Z.Z.; Chen, C.; Zeng, Z.; Yang, H.; Oh, J.; Chen, L.; Lu, S.C. Mechanism and significance of increased glutathione level in human hepatocellular carcinoma and liver regeneration. FASEB J. 2001, 15, 19-21. [CrossRef] [PubMed]

114. Teoh-Fitzgerald, M.L.T.; Fitzgerald, M.P.; Jensen, T.J.; Futscher, B.W.; Domann, F.E. Genetic and Epigenetic Inactivation of Extracellular Superoxide Dismutase Promotes an Invasive Phenotype in Human Lung Cancer by Disrupting ECM Homeostasis. Mol. Cancer Res. 2012, 10, 40-51. [CrossRef] [PubMed]

115. Yoo, D.G.; Song, Y.J.; Cho, E.J.; Lee, S.K.; Park, J.B.; Yu, J.H.; Lim, S.P.; Kim, J.M.; Jeon, B.H. Alteration of APE1/ref-1 expression in non-small cell lung cancer: The implications of impaired extracellular superoxide dismutase and catalase antioxidant systems. Lung Cancer 2008, 60, 277-284. [CrossRef] [PubMed]

116. Svensk, A.M.; Soini, Y.; Pääkkö, P.; Hirvikoski, P.; Kinnula, V.L. Differential Expression of Superoxide Dismutases in Lung Cancer. Am. J. Clin. Pathol. 2004, 122, 395-404. [CrossRef] [PubMed]

117. Teoh-Fitzgerald, M.L.; Fitzgerald, M.P.; Zhong, W.; Askeland, R.W.; Domann, F.E. Epigenetic reprogramming governs EcSOD expression during human mammary epithelial cell differentiation, tumorigenesis and metastasis. Oncogene 2014, 33, 358-368. [CrossRef] [PubMed]

118. Hubackova, M.; Vaclavikova, R.; Ehrlichova, M.; Mrhalova, M.; Kodet, R.; Kubackova, K.; Vrána, D.; Gut, I.; Soucek, P. Association of superoxide dismutases and NAD $(\mathrm{P}) \mathrm{H}$ quinone oxidoreductases with prognosis of patients with breast carcinomas. Int. J. Cancer 2012, 130, 338-348. [CrossRef]

119. Chaiswing, L.; Zhong, W.; Oberley, T.D. Increasing discordant antioxidant protein levels and enzymatic activities contribute to increasing redox imbalance observed during human prostate cancer progression. Free Radic. Biol. Med. 2014, 67, 342-352. [CrossRef]

120. Kim, J.; Mizokami, A.; Shin, M.; Izumi, K.; Konaka, H.; Kadono, Y.; Kitagawa, Y.; Keller, E.T.; Zhang, J.; Namiki, M. SOD3 acts as a tumor suppressor in PC-3 prostate cancer cells via hydrogen peroxide accumulation. Anticancer Res. 2014, 34, 2821-2831.

121. O’Leary, B.R.; Fath, M.A.; Bellizzi, A.M.; Hrabe, J.E.; Button, A.M.; Allen, B.G.; Case, A.J.; Altekruse, S.; Wagner, B.A.; Buettner, G.R.; et al. Loss of SOD3 (EcSOD) Expression Promotes an Aggressive Phenotype in Human Pancreatic Ductal Adenocarcinoma. Clin. Cancer Res. 2015, 21, 1741-1751. [CrossRef]

122. Liu, X.; Xu, Y.; Meng, Q.; Zheng, Q.; Wu, J.; Wang, C.; Jia, W.; Figeys, D.; Chang, Y.; Zhou, H. Proteomic analysis of minute amount of colonic biopsies by enteroscopy sampling. Biochem. Biophys. Res. Commun. 2016, 476, 286-292. [CrossRef]

123. Parascandolo, A.; Rappa, F.; Cappello, F.; Kim, J.; Cantu, D.A.; Chen, H.; Mazzoccoli, G.; Hematti, P.; Castellone, M.D.; Salvatore, M.; et al. Extracellular Superoxide Dismutase Expression in Papillary Thyroid Cancer Mesenchymal Stem/Stromal Cells Modulates Cancer Cell Growth and Migration. Sci. Rep. 2017, 7, 41416. [CrossRef]

124. Subbannayya, Y.; Mir, S.A.; Renuse, S.; Manda, S.S.; Pinto, S.M.; Puttamallesh, V.N.; Solanki, H.S.; Manju, H.C.; Syed, N.; Sharma, R.; et al. Identification of differentially expressed serum proteins in gastric adenocarcinoma. J. Proteom. 2015, 127, 80-88. [CrossRef] [PubMed]

125. Suzuki, C.; Daigo, Y.; Kikuchi, T.; Katagiri, T.; Nakamura, Y. Identification of COX17 as a therapeutic target for non-small cell lung cancer. Cancer Res. 2003, 63, 7038-7041. [PubMed] 
126. Prusinkiewicz, M.A.; Gameiro, S.F.; Ghasemi, F.; Dodge, M.J.; Zeng, P.Y.F.; Maekebay, H.; Barrett, J.W.; Nichols, A.C.; Mymryk, J.S. Survival-Associated Metabolic Genes in Human Papillomavirus-Positive Head and Neck Cancers. Cancers 2020, 12, 253. [CrossRef] [PubMed]

127. Blockhuys, S.; Wittung-Stafshede, P. Copper chaperone Atox1 plays role in breast cancer cell migration. Biochem. Biophys. Res. Commun. 2017, 483, 301-304. [CrossRef] [PubMed]

128. Blockhuys, S.; Brady, D.C.; Wittung-Stafshede, P. Evaluation of copper chaperone ATOX1 as prognostic biomarker in breast cancer. Breast Cancer 2020, 27, 505-509. [CrossRef]

129. Blockhuys, S.; Zhang, X.; Wittung-Stafshede, P. Single-cell tracking demonstrates copper chaperone Atox1 to be required for breast cancer cell migration. Proc. Natl. Acad. Sci. USA 2020, 117, 2014-2019. [CrossRef]

130. Ashino, T.; Kohno, T.; Sudhahar, V.; Ash, D.; Ushio-Fukai, M.; Fukai, T. Copper transporter ATP7A interacts with IQGAP1, a Rac1 binding scaffolding protein: Role in PDGF-induced VSMC migration and vascular remodeling. Am. J. Physiol. Cell Physiol. 2018, 315, C850-C862. [CrossRef]

131. An Online Survival Analysis Tool to Rapidly Assess the Effect of 22,277 Genes on Breast Cancer Prognosis Using Microarray Data of 1,809 Patients-PubMed. Available online: https://pubmed.ncbi.nlm.nih.gov/ 20020197/ (accessed on 3 November 2020).

132. Xiao, Q.; Ge, G. Lysyl Oxidase, Extracellular Matrix Remodeling and Cancer Metastasis. Cancer Microenviron. 2012, 5, 261-273. [CrossRef]

133. Baker, A.M.; Bird, D.; Lang, G.; Cox, T.R.; Erler, J.T. Lysyl oxidase enzymatic function increases stiffness to drive colorectal cancer progression through FAK. Oncogene 2013, 32, 1863-1868. [CrossRef]

134. Payne, S.L.; Fogelgren, B.; Hess, A.R.; Seftor, E.A.; Wiley, E.L.; Fong, S.F.T.; Csiszar, K.; Hendrix, M.J.C.; Kirschmann, D.A. Lysyl Oxidase Regulates Breast Cancer Cell Migration and Adhesion through a Hydrogen Peroxide-Mediated Mechanism. Cancer Res. 2005, 65, 11429-11436. [CrossRef] [PubMed]

135. Barker, H.E.; Cox, T.R.; Erler, J.T. The rationale for targeting the LOX family in cancer. Nat. Rev. Cancer 2012, 12, 540-552. [CrossRef] [PubMed]

136. Han, Y.; Lian, S.; Cui, X.; Meng, K.; Győrffy, B.; Jin, T.; Huang, D. Potential options for managing LOX+ ERbreast cancer patients. Oncotarget 2016, 7, 32893-32901. [CrossRef] [PubMed]

137. Shanbhag, V.; Jasmer-McDonald, K.; Zhu, S.; Martin, A.L.; Gudekar, N.; Khan, A.; Ladomersky, E.; Singh, K.; Weisman, G.A.; Petris, M.J. ATP7A delivers copper to the lysyl oxidase family of enzymes and promotes tumorigenesis and metastasis. Proc. Natl. Acad. Sci. USA 2019, 116, 6836-6841. [CrossRef] [PubMed]

138. Martinez-Balibrea, E.; Martínez-Cardús, A.; Musulén, E.; Ginés, A.; Manzano, J.L.; Aranda, E.; Plasencia, C.; Neamati, N.; Abad, A. Increased levels of copper efflux transporter ATP7B are associated with poor outcome in colorectal cancer patients receiving oxaliplatin-based chemotherapy. Int. J. Cancer 2009, 124, 2905-2910. [CrossRef]

139. Nakagawa, T.; Inoue, Y.; Kodama, H.; Yamazaki, H.; Kawai, K.; Suemizu, H.; Masuda, R.; Iwazaki, M.; Yamada, S.; Ueyama, Y.; et al. Expression of copper-transporting P-type adenosine triphosphatase (ATP7B) correlates with cisplatin resistance in human non-small cell lung cancer xenografts. Oncol. Rep. 2008, 20, 265-270. [CrossRef]

140. Nakayama, K. Prognostic Value of the Cu-Transporting ATPase in Ovarian Carcinoma Patients Receiving Cisplatin-Based Chemotherapy. Clin. Cancer Res. 2004, 10, 2804-2811. [CrossRef]

141. Godwin, A.K.; Meister, A.; O’Dwyer, P.J.; Huang, C.S.; Hamilton, T.C.; Anderson, M.E. High resistance to cisplatin in human ovarian cancer cell lines is associated with marked increase of glutathione synthesis. Proc. Natl. Acad. Sci. USA 1992, 89, 3070-3074. [CrossRef]

142. Jamali, B.; Nakhjavani, M.; Hosseinzadeh, L.; Amidi, S.; Nikounezhad, N.; Shirazi, F.H. Intracellular GSH Alterations and Its Relationship to Level of Resistance following Exposure to Cisplatin in Cancer Cells. Iran. J. Pharm. Res. 2015, 14, 513-519.

143. Holzer, A.K.; Varki, N.M.; Le, Q.T.; Gibson, M.A.; Naredi, P.; Howell, S.B. Expression of the Human Copper Influx Transporter 1 in Normal and Malignant Human Tissues. J. Histochem. Cytochem. 2006, 54, 1041-1049. [CrossRef]

144. Song, I.S.; Savaraj, N.; Siddik, Z.H.; Liu, P.; Wei, Y.; Wu, C.J.; Kuo, M.T. Role of human copper transporter Ctr1 in the transport of platinum-based antitumor agents in cisplatin-sensitive and cisplatin-resistant cells. Mol. Cancer Ther. 2004, 3, 1543-1549. [PubMed] 
145. Liang, Z.D.; Stockton, D.; Savaraj, N.; Tien Kuo, M. Mechanistic Comparison of Human High-Affinity Copper Transporter 1-Mediated Transport between Copper Ion and Cisplatin. Mol. Pharmacol. 2009, 76, 843-853. [CrossRef] [PubMed]

146. Ishida, S.; McCormick, F.; Smith-McCune, K.; Hanahan, D. Enhancing Tumor-Specific Uptake of the Anticancer Drug Cisplatin with a Copper Chelator. Cancer Cell 2010, 17, 574-583. [CrossRef] [PubMed]

147. Howell, S.B.; Safaei, R.; Larson, C.A.; Sailor, M.J. Copper Transporters and the Cellular Pharmacology of the Platinum-Containing Cancer Drugs. Mol. Pharmacol. 2010, 77, 887-894. [CrossRef] [PubMed]

148. Amable, L. Cisplatin resistance and opportunities for precision medicine. Pharmacol. Res. 2016, 106, 27-36. [CrossRef]

149. Denoyer, D.; Masaldan, S.; La Fontaine, S.; Cater, M.A. Targeting copper in cancer therapy: 'Copper That Cancer'. Metallomics 2015, 7, 1459-1476. [CrossRef]

150. Wu, X.; Yuan, S.; Wang, E.; Tong, Y.; Ma, G.; Wei, K.; Liu, Y. Platinum transfer from hCTR1 to Atox1 is dependent on the type of platinum complex. Metallomics 2017, 9, 546-555. [CrossRef]

151. Arnesano, F.; Banci, L.; Bertini, I.; Felli, I.C.; Losacco, M.; Natile, G. Probing the Interaction of Cisplatin with the Human Copper Chaperone Atox1 by Solution and In-Cell NMR Spectroscopy. J. Am. Chem. Soc. 2011, 133, 18361-18369. [CrossRef]

152. Boal, A.K.; Rosenzweig, A.C. Crystal Structures of Cisplatin Bound to a Human Copper Chaperone. J. Am. Chem. Soc. 2009, 131, 14196-14197. [CrossRef]

153. Tadini-Buoninsegni, F.; Bartolommei, G.; Moncelli, M.R.; Inesi, G.; Galliani, A.; Sinisi, M.; Losacco, M.; Natile, G.; Arnesano, F. Translocation of Platinum Anticancer Drugs by Human Copper ATPases ATP7A and ATP7B. Angew. Chem. Int. Ed. 2014, 53, 1297-1301. [CrossRef]

154. Dolgova, N.V.; Nokhrin, S.; Yu, C.H.; George, G.N.; Dmitriev, O.Y. Copper chaperone Atox1 interacts with the metal-binding domain of Wilson's disease protein in cisplatin detoxification. Biochem. J. 2013, 454, 147-156. [CrossRef] [PubMed]

155. Petruzzelli, R.; Polishchuk, R.S. Activity and Trafficking of Copper-Transporting ATPases in Tumor Development and Defense against Platinum-Based Drugs. Cells 2019, 8, 1080. [CrossRef] [PubMed]

156. Katano, K.; Kondo, A.; Safaei, R.; Holzer, A.; Samimi, G.; Mishima, M.; Kuo, Y.M.; Rochdi, M.; Howell, S.B. Acquisition of resistance to cisplatin is accompanied by changes in the cellular pharmacology of copper. Cancer Res. 2002, 62, 6559-6565. [PubMed]

157. Kalayda, G.V.; Wagner, C.H.; Buss, I.; Reedijk, J.; Jaehde, U. Altered localisation of the copper efflux transporters ATP7A and ATP7B associated with cisplatin resistance in human ovarian carcinoma cells. BMC Cancer 2008, 8, 175. [CrossRef] [PubMed]

158. Huang, C.P.; Fofana, M.; Chan, J.; Chang, C.J.; Howell, S.B. Copper transporter 2 regulates intracellular copper and sensitivity to cisplatin. Met. Integr. Biometal Sci. 2014, 6, 654-661. [CrossRef]

159. Mariniello, M.; Petruzzelli, R.; Wanderlingh, L.G.; La Montagna, R.; Carissimo, A.; Pane, F.; Amoresano, A.; Ilyechova, E.Y.; Galagudza, M.M.; Catalano, F.; et al. Synthetic Lethality Screening Identifies FDA-Approved Drugs that Overcome ATP7B-Mediated Tolerance of Tumor Cells to Cisplatin. Cancers 2020, 12, 608. [CrossRef]

160. Wang, J.; Luo, C.; Shan, C.; You, Q.; Lu, J.; Elf, S.; Zhou, Y.; Wen, Y.; Vinkenborg, J.L.; Fan, J.; et al. Inhibition of human copper trafficking by a small molecule significantly attenuates cancer cell proliferation. Nat. Chem. 2015, 7, 968-979. [CrossRef]

161. Li, Y.; Liang, R.; Zhang, X.; Wang, J.; Shan, C.; Liu, S.; Li, L.; Zhang, S. Copper Chaperone for Superoxide Dismutase Promotes Breast Cancer Cell Proliferation and Migration via ROS-Mediated MAPK/ERK Signaling. Front. Pharmacol. 2019, 10, 356. [CrossRef]

162. Cai, H.; Peng, F. Knockdown of copper chaperone antioxidant-1 by RNA interference inhibits copper-stimulated proliferation of non-small cell lung carcinoma cells. Oncol. Rep. 2013, 30, 269-275. [CrossRef]

163. Griess, B.; Tom, E.; Domann, F.; Teoh-Fitzgerald, M. Extracellular superoxide dismutase and its role in cancer. Free Radic. Biol. Med. 2017, 112, 464-479. [CrossRef]

164. Soini, Y.; Kallio, J.; Hirvikoski, P.; Helin, H.; Kellokumpu-Lehtinen, P.; Tammela, T.; Peltoniemi, M.; Martikainen, P.; Kinnula, L. Antioxidant enzymes in renal cell carcinoma. Histol. Histopathol. 2005, 157-165. [CrossRef] 
165. Laukkanen, M.O. Extracellular Superoxide Dismutase: Growth Promoter or Tumor Suppressor? Oxid. Med. Cell. Longev. 2016, 2016, 3612589. [CrossRef] [PubMed]

166. Galluzzi, L.; Pietrocola, F.; Bravo-San Pedro, J.M.; Amaravadi, R.K.; Baehrecke, E.H.; Cecconi, F.; Codogno, P.; Debnath, J.; Gewirtz, D.A.; Karantza, V.; et al. Autophagy in malignant transformation and cancer progression. EMBO J. 2015, 34, 856-880. [CrossRef] [PubMed]

167. Polishchuk, E.V.; Merolla, A.; Lichtmannegger, J.; Romano, A.; Indrieri, A.; Ilyechova, E.Y.; Concilli, M.; De Cegli, R.; Crispino, R.; Mariniello, M.; et al. Activation of Autophagy, Observed in Liver Tissues From Patients With Wilson Disease and From ATP7B-Deficient Animals, Protects Hepatocytes From Copper-Induced Apoptosis. Gastroenterology 2019, 156, 1173-1189. [CrossRef] [PubMed]

168. Carretero, J.; Obrador, E.; Anasagasti, M.J.; Martin, J.J.; Vidal-Vanaclocha, F.; Estrela, J.M. Growth-associated changes in glutathione content correlate with liver metastatic activity of B16 melanoma cells. Clin. Exp. Metastasis 1999, 17, 567-574. [CrossRef] [PubMed]

169. Hakimi, A.A.; Reznik, E.; Lee, C.H.; Creighton, C.J.; Brannon, A.R.; Luna, A.; Aksoy, B.A.; Liu, E.M.; Shen, R.; Lee, W.; et al. An Integrated Metabolic Atlas of Clear Cell Renal Cell Carcinoma. Cancer Cell 2016, 29, 104-116. [CrossRef]

170. Vargas, A.J.; Sittadjody, S.; Thangasamy, T.; Mendoza, E.E.; Limesand, K.H.; Burd, R. Exploiting Tyrosinase Expression and Activity in Melanocytic Tumors: Quercetin and the Central Role of p53. Integr. Cancer Ther. 2011, 10, 328-340. [CrossRef]

171. Yigit, E.; Gönüllü, G.; Yücel, İ; Turgut, M.; Erdem, D.; Çakar, B. Relation between hemostatic parameters and prognostic/predictive factors in breast cancer. Eur. J. Intern. Med. 2008, 19, 602-607. [CrossRef]

172. Auwerda, J.J.A.; Sonneveld, P.; de Maat, M.P.M.; Leebeek, F.W.G. Prothrombotic coagulation abnormalities in patients with newly diagnosed multiple myeloma. Haematologica 2007, 92, 279-280. [CrossRef]

173. Battistelli, S.; Stefanoni, M.; Lorenzi, B.; Dell'avanzato, R.; Varrone, F.; Pascucci, A.; Petrioli, R.; Vittoria, A. Coagulation factor levels in non-metastatic colorectal cancer patients. Int. J. Biol. Markers 2008, 23, 36-41. [CrossRef]

174. Minnema, M.C.; Fijnheer, R.; De Groot, P.G.; Lokhorst, H.M. Extremely high levels of von Willebrand factor antigen and of procoagulant factor VIII found in multiple myeloma patients are associated with activity status but not with thalidomide treatment: High levels of VWF-ag, FVIII and thalidomide. J. Thromb. Haemost. 2003, 1, 445-449. [CrossRef] [PubMed]

175. Gieseler, F.; Lühr, I.; Kunze, T.; Mundhenke, C.; Maass, N.; Erhart, T.; Denker, M.; Beckmann, D.; Tiemann, M.; Schulte, C.; et al. Activated coagulation factors in human malignant effusions and their contribution to cancer cell metastasis and therapy. Thromb. Haemost. 2007, 97, 1023-1030. [CrossRef]

176. Weekley, C.M.; He, C. Developing drugs targeting transition metal homeostasis. Curr. Opin. Chem. Biol. 2017, 37, 26-32. [CrossRef] [PubMed]

177. Denoyer, D.; Pearson, H.B.; Clatworthy, S.A.S.; Smith, Z.M.; Francis, P.S.; Llanos, R.M.; Volitakis, I.; Phillips, W.A.; Meggyesy, P.M.; Masaldan, S.; et al. Copper as a target for prostate cancer therapeutics: Copper-ionophore pharmacology and altering systemic copper distribution. Oncotarget 2016, 7, 37064-37080. [CrossRef] [PubMed]

178. Matsubara, T.; Saura, R.; Hirohata, K.; Ziff, M. Inhibition of human endothelial cell proliferation in vitro and neovascularization in vivo by D-penicillamine. J. Clin. Investig. 1989, 83, 158-167. [CrossRef]

179. Yoshii, J.; Yoshiji, H.; Kuriyama, S.; Ikenaka, Y.; Noguchi, R.; Okuda, H.; Tsujinoue, H.; Nakatani, T.; Kishida, H.; Nakae, D.; et al. The copper-chelating agent, trientine, suppresses tumor development and angiogenesis in the murine hepatocellular carcinoma cells. Int. J. Cancer 2001, 94, 768-773. [CrossRef] [PubMed]

180. Moriguchi, M.; Nakajima, T.; Kimura, H.; Watanabe, T.; Takashima, H.; Mitsumoto, Y.; Katagishi, T.; Okanoue, T.; Kagawa, K. The copper chelator trientine has an antiangiogenic effect against hepatocellular carcinoma, possibly through inhibition of interleukin-8 production. Int. J. Cancer 2002, 102, 445-452. [CrossRef]

181. Turski, M.L.; Brady, D.C.; Kim, H.J.; Kim, B.E.; Nose, Y.; Counter, C.M.; Winge, D.R.; Thiele, D.J. A Novel Role for Copper in Ras/Mitogen-Activated Protein Kinase Signaling. Mol. Cell. Biol. 2012, 32, 1284-1295. [CrossRef]

182. Davies, H.; Bignell, G.R.; Cox, C.; Stephens, P.; Edkins, S.; Clegg, S.; Teague, J.; Woffendin, H.; Garnett, M.J.; Bottomley, W.; et al. Mutations of the BRAF gene in human cancer. Nature 2002, 417, 949-954. [CrossRef] 
183. Brady, D.C.; Crowe, M.S.; Greenberg, D.N.; Counter, C.M. Copper Chelation Inhibits BRAF V600E -Driven Melanomagenesis and Counters Resistance to BRAF V600E and MEK1/2 Inhibitors. Cancer Res. 2017, 77, 6240-6252. [CrossRef]

184. Baldari, S.; Di Rocco, G.; Heffern, M.C.; Su, T.A.; Chang, C.J.; Toietta, G. Effects of Copper Chelation on BRAFV600E Positive Colon Carcinoma Cells. Cancers 2019, 11, 659. [CrossRef] [PubMed]

185. Hecht, S.M. Bleomycin: New Perspectives on the Mechanism of Action ${ }^{1}$. J. Nat. Prod. 2000, 63, 158-168. [CrossRef] [PubMed]

186. Chen, J.; Stubbe, J. Bleomycins: Towards better therapeutics. Nat. Rev. Cancer 2005, 5, 102-112. [CrossRef] [PubMed]

187. Einhorn, L.H. Curing metastatic testicular cancer. Proc. Natl. Acad. Sci. USA 2002, 99, 4592-4595. [CrossRef] [PubMed]

188. Devassy, J.G.; Nwachukwu, I.D.; Jones, P.J.H. Curcumin and cancer: Barriers to obtaining a health claim. Nutr. Rev. 2015, 73, 155-165. [CrossRef] [PubMed]

189. Helsel, M.E.; Franz, K.J. Pharmacological activity of metal binding agents that alter copper bioavailability. Dalton Trans. 2015, 44, 8760-8770. [CrossRef]

190. Mao, X.; Schimmer, A. The toxicology of Clioquinol. Toxicol. Lett. 2008, 182, 1-6. [CrossRef]

191. Khan, R.; Khan, H.; Abdullah, Y.; Dou, Q.P. Feasibility of Repurposing Clioquinol for Cancer Therapy. Recent Patents Anticancer Drug Discov. 2020, 15, 14-31. [CrossRef]

192. Allensworth, J.L.; Evans, M.K.; Bertucci, F.; Aldrich, A.J.; Festa, R.A.; Finetti, P.; Ueno, N.T.; Safi, R.; McDonnell, D.P.; Thiele, D.J.; et al. Disulfiram (DSF) acts as a copper ionophore to induce copper-dependent oxidative stress and mediate anti-tumor efficacy in inflammatory breast cancer. Mol. Oncol. 2015, 9, 1155-1168. [CrossRef]

193. Jiao, Y.; Hannafon, B.N.; Zhang, R.R.; Fung, K.M.; Ding, W.Q. Docosahexaenoic acid and disulfiram act in concert to kill cancer cells: A mutual enhancement of their anticancer actions. Oncotarget 2017, 8, 17908-17920. [CrossRef]

194. Zhang, H.; Chen, D.; Ringler, J.; Chen, W.; Cui, Q.C.; Ethier, S.P.; Dou, Q.P.; Wu, G. Disulfiram Treatment Facilitates Phosphoinositide 3-Kinase Inhibition in Human Breast Cancer Cells In vitro and In vivo. Cancer Res. 2010, 70, 3996-4004. [CrossRef] [PubMed]

195. Safi, R.; Nelson, E.R.; Chitneni, S.K.; Franz, K.J.; George, D.J.; Zalutsky, M.R.; McDonnell, D.P. Copper Signaling Axis as a Target for Prostate Cancer Therapeutics. Cancer Res. 2014, 74, 5819-5831. [CrossRef] [PubMed]

196. Cater, M.A.; Pearson, H.B.; Wolyniec, K.; Klaver, P.; Bilandzic, M.; Paterson, B.M.; Bush, A.I.; Humbert, P.O.; La Fontaine, S.; Donnelly, P.S.; et al. Increasing Intracellular Bioavailable Copper Selectively Targets Prostate Cancer Cells. ACS Chem. Biol. 2013, 8, 1621-1631. [CrossRef] [PubMed]

197. Wadhwa, S.; Mumper, R.J. Intracellular Delivery of the Reactive Oxygen Species Generating Agent D-Penicillamine upon Conjugation to Poly-L-glutamic Acid. Mol. Pharm. 2010, 7, 854-862. [CrossRef]

198. Luo, C.Q.; Xing, L.; Cui, P.F.; Qiao, J.B.; He, Y.J.; Chen, B.A.; Jin, L.; Jiang, H.L. Curcumin-coordinated nanoparticles with improved stability for reactive oxygen species-responsive drug delivery in lung cancer therapy. Int. J. Nanomed. 2017, 12, 855-869. [CrossRef]

199. Yallapu, M.M.; Nagesh, P.K.B.; Jaggi, M.; Chauhan, S.C. Therapeutic Applications of Curcumin Nanoformulations. AAPS J. 2015, 17, 1341-1356. [CrossRef]

200. Norum, O.J.; Fremstedal, A.S.V.; Weyergang, A.; Golab, J.; Berg, K. Photochemical delivery of bleomycin induces T-cell activation of importance for curative effect and systemic anti-tumor immunity. J. Control. Release 2017, 268, 120-127. [CrossRef] [PubMed]

201. Zhou, M.; Tian, M.; Li, C. Copper-Based Nanomaterials for Cancer Imaging and Therapy. Bioconjug. Chem. 2016, 27, 1188-1199. [CrossRef]

202. Guo, L.; Yan, D.D.; Yang, D.; Li, Y.; Wang, X.; Zalewski, O.; Yan, B.; Lu, W. Combinatorial Photothermal and Immuno Cancer Therapy Using Chitosan-Coated Hollow Copper Sulfide Nanoparticles. ACS Nano 2014, 8, 5670-5681. [CrossRef]

203. Li, N.; Sun, Q.; Yu, Z.; Gao, X.; Pan, W.; Wan, X.; Tang, B. Nuclear-Targeted Photothermal Therapy Prevents Cancer Recurrence with Near-Infrared Triggered Copper Sulfide Nanoparticles. ACS Nano 2018, 12, 5197-5206. [CrossRef] 
204. Goswami, U.; Dutta, A.; Raza, A.; Kandimalla, R.; Kalita, S.; Ghosh, S.S.; Chattopadhyay, A. Transferrin-Copper Nanocluster-Doxorubicin Nanoparticles as Targeted Theranostic Cancer Nanodrug. ACS Appl. Mater. Interfaces 2018, 10, 3282-3294. [CrossRef] [PubMed]

205. Boschi, A.; Martini, P.; Janevik-Ivanovska, E.; Duatti, A. The emerging role of copper-64 radiopharmaceuticals as cancer theranostics. Drug Discov. Today 2018, 23, 1489-1501. [CrossRef] [PubMed]

206. Shokeen, M.; Wadas, T.J. The Development of Copper Radiopharmaceuticals for Imaging and Therapy. Med. Chem. 2011, 7, 413-429. [CrossRef] [PubMed]

207. Lewis, J.S.; Laforest, R.; Buettner, T.L.; Song, S.K.; Fujibayashi, Y.; Connett, J.M.; Welch, M.J. Copper-64-diacetyl-bis(N4-methylthiosemicarbazone): An agent for radiotherapy. Proc. Natl. Acad. Sci. USA 2001, 98, 1206-1211. [CrossRef] [PubMed]

208. Knogler, K.; Grünberg, J.; Zimmermann, K.; Cohrs, S.; Honer, M.; Ametamey, S.; Altevogt, P.; Fogel, M.; Schubiger, P.A.; Novak-Hofer, I. Copper-67 Radioimmunotherapy and Growth Inhibition by Anti-L1-Cell Adhesion Molecule Monoclonal Antibodies in a Therapy Model of Ovarian Cancer Metastasis. Clin. Cancer Res. 2007, 13, 603-611. [CrossRef]

209. Santini, C.; Pellei, M.; Gandin, V.; Porchia, M.; Tisato, F.; Marzano, C. Advances in Copper Complexes as Anticancer Agents. Chem. Rev. 2014, 114, 815-862. [CrossRef]

210. Daniel, K.G.; Gupta, P.; Harbach, R.H.; Guida, W.C.; Dou, Q.P. Organic copper complexes as a new class of proteasome inhibitors and apoptosis inducers in human cancer cells. Biochem. Pharmacol. 2004, 67, 1139-1151. [CrossRef]

211. Kunjachan, S.; Kotb, S.; Pola, R.; Pechar, M.; Kumar, R.; Singh, B.; Gremse, F.; Taleeli, R.; Trichard, F.; Motto-Ros, V.; et al. Selective Priming of Tumor Blood Vessels by Radiation Therapy Enhances Nanodrug Delivery. Sci. Rep. 2019, 9, 15844. [CrossRef]

212. Bulin, A.; Broekgaarden, M.; Chaput, F.; Baisamy, V.; Garrevoet, J.; Busser, B.; Brueckner, D.; Youssef, A.; Ravanat, J.; Dujardin, C.; et al. Radiation Dose-Enhancement Is a Potent Radiotherapeutic Effect of Rare-Earth Composite Nanoscintillators in Preclinical Models of Glioblastoma. Adv. Sci. 2020, 7, 2001675. [CrossRef]

213. Batinic-Haberle, I.; Tovmasyan, A.; Spasojevic, I. An educational overview of the chemistry, biochemistry and therapeutic aspects of Mn porphyrins-From superoxide dismutation to $\mathrm{H}_{2} \mathrm{O}_{2}$-driven pathways. Redox Biol. 2015, 5, 43-65. [CrossRef]

214. Johnston, K.A.; Lopez, K.M. Lysyl oxidase in cancer inhibition and metastasis. Cancer Lett. 2018, 417, $174-181$. [CrossRef] [PubMed]

215. Trackman, P.C. Lysyl Oxidase Isoforms and Potential Therapeutic Opportunities for Fibrosis and Cancer. Expert Opin. Ther. Targets 2016, 20, 935-945. [CrossRef] [PubMed]

Publisher's Note: MDPI stays neutral with regard to jurisdictional claims in published maps and institutional affiliations.

(C) 2020 by the authors. Licensee MDPI, Basel, Switzerland. This article is an open access article distributed under the terms and conditions of the Creative Commons Attribution (CC BY) license (http://creativecommons.org/licenses/by/4.0/). 